\title{
Two Probable Cases of Infection with Treponema pallidum during the Neolithic Period in Northern Vietnam (ca. 2000-1500 B.C.)
}

\author{
Melandri Vlok, ${ }^{\mathrm{a} *}$ Marc Fredrick Oxenham, ${ }^{\mathrm{b}, \mathrm{c}}$ Kate Domett, ${ }^{\mathrm{d}}$ Tran Thi Minh, ${ }^{\mathrm{e}}$ \\ Nguyen Thi Mai Huong, ${ }^{e}$ Hirofumi Matsumura, ${ }^{f}$ Hiep Hoang Trinh, ${ }^{e}$ \\ Thomas Higham, ${ }^{9}$ Charles Higham, ${ }^{\text {h }}$ Nghia Truong Huu, ${ }^{e}$ and \\ Hallie Ruth Buckley ${ }^{\mathrm{a}}$ \\ aDepartment of Anatomy, University of Otago, Dunedin, New Zealand \\ bchool of Archaeology and Anthropology, The Australian National University, Canberra, Australia \\ 'School of Archaeology, University of Aberdeen, Scotland, UK \\ ${ }^{\mathrm{d} C}$ College of Medicine and Dentistry, James Cook University, Townsville, Australia \\ 'Institute of Archaeology, Hanoi, Vietnam \\ fSchool of Health Sciences, Sapporo Medical University, Sapporo, Japan \\ g Oxford Radiocarbon Accelerator Unit, University of Oxford, Oxford OX1 3QY, UK

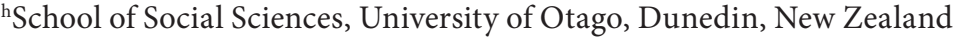 \\ ${ }^{\star}$ Correspondence to: Melandri Vlok, Department of Anatomy, University of Otago, 270 Great King Street, \\ Dunedin 9016, New Zealand \\ e-mail: Melandri.vlok@postgrad.otago.ac.nz
}

This research was supported by a National Geographic Early Career Grant (EC-54332R-18), a Royal Society of New Zealand Skinner Fund Grant, and a University of Otago Doctoral Scholarship.

ABSTRACT Skeletal evidence of two probable cases of treponematosis, caused by infection with the bacterium Treponema pallidum, from the northern Vietnamese early Neolithic site of Man Bac (1906-1523 cal B.C.) is described. The presence of nodes of subperiosteal new bone directly associated with superficial focal cavitations in a young adult male and a seven-year-old child are strongly diagnostic for treponemal disease. Climatic and epidemiological contexts suggest yaws (Treponema pallidum pertenue) as the most likely causative treponeme. This evidence is the oldest discovered in the Asia-Pacific region and is the first well-established preColumbian example in this region in terms of diagnosis and secure dating. The coastal ecology, sedentary settlement, and high fertility at the site of Man Bac all provided a biosocial context conducive to the spread of treponemal disease among inhabitants of the site. Co-morbidity with scurvy in both individuals demonstrates that malnutrition during the agricultural transition may have exacerbated the expression of treponematosis in this community.

Man Bac is a site of great regional importance owing to its role during the Neolithic transition of Mainland Southeast Asia. During this transition, approximately 4,000 years ago, farmers migrating from southern China into Southeast Asia influenced a number of changes in subsistence and demography and potentially introduced new infectious diseases such as treponematosis to indigenous forager communities. The findings presented here may encourage reevaluation of existing Southeast Asian skeletal samples and demonstrate the importance of using weighted diagnostic criteria for future reporting of treponematosis cases.

Keywords: agricultural transition; Southeast Asia; yaws 
Hai trường hợp nhiều khả năng mắc bệnh ghẻ cóc do nhiễm vi khuẩn Treponema pallidum, thuộc di chỉ Mán Bạc sơ kì đá mới Việt Nam (cal 1906-1523 B.C.) được mô tả trên bằng chứng di cốt. Sự có mặt của các hạt xương mới dưới màng xương trực tiếp liên quan đến các lỗ ổ bể mặt ở một nam trẻ tuổi trưởng thành và một trẻ em 7 tuổi là chẩn đoán nhiểu khả năng cho bệnh này. Bối cảnh khí hậu và dịch tễ học cho thấy bệnh ghẻ cóc do nhiễm xoắn khuẩn Treponema pallidum pertenue là nguyên nhân phổ biến nhất. Bằng chứng trên được phát hiện muộn nhất ở khu vực Châu Á-Thái Bình Dương và là một ví dụ điển hình đâu tiên giai đoạn tiền Columbia trong khu vực này dựa vào chẩn đoán và định niên đại chính xác. Sinh thái biển, lối sống ít di động, và tỷ lệ sinh sản cao ở di chỉ Mán Bạc, tất cả đã tạo ra sự tương tác giữa các yếu tố sinh học và xã hội thuận lợi cho việc lây lan bệnh ghẻ cóc giữa các cư dân thuộc di chỉ này. Cùng với đó là sự mắc bệnh thiếu vitamin $\mathrm{C}$ (scurvy) ở cả hai cá thể trên chỉ ra rằng sự suy dinh dưỡng trong suốt quá trình chuyển tiếp nông nghiệp có thể trâmm trọng hơn và biểu hiện bệnh ghẻ cóc ở cộng đông này.

Mán Bạc là một di chỉ vùng quan trọng bởi vì nó nằm trong ranh giới giai đoạn chuyển tiếp Đá Mới của Đông Nam Á lục địa. Trong suốt bước chuyển này, khoảng 4000 năm cách đây, các cư dân nông nghiệp di cư từ miền nam Trung Quốc vào Đông Nam Á đã ảnh hưởng nhiều thay đổi trong phương thức sinh kế, dân số, và mang theo bệnh nhiễm trùng mới tiềm ẩn như là bệnh ghẻ cóc vào các cộng đông nông nghiệp bản địa . Các phát hiện trình bày trên đây hi vọng sẽ là khởi đầu đánh giá lại về sự tôn tại các di cốt Đông Nam Á và minh họa tầm quan trọng của việc sử dụng tiêu chí chẩn đoán tin cậy về các trường hợp bệnh ghẻ cóc cho nghiên cứu tiếp theo.

In recent years, intensive archaeological and bioarchaeological research in Mainland Southeast Asia (MSEA) has described a unique agricultural transition that had a significant impact on the region's genetics, demographics, social organization, and subsistence base (Lipson et al. 2018; Matsumura and Oxenham 2014; Oxenham and Buckley 2016). Strong morphological evidence for the admixture of local indigenous populations and migrants from southern China (Matsumura and Oxenham 2013a, 2013b, 2014; Matsumura et al. 2008, 2019) has been supported by recent genomewide ancient DNA analyses (Lipson et al. 2018; McColl et al. 2018). The evidence indicates that co-habitation and genetic admixture of agriculturalists and local foragers resulted in considerable social and demographic change at this time in MSEA (Lipson et al.2018; McColl et al. 2018; Oxenham et al. 2011). While there remains a considerable focus on subsistence transitions and its impact on general health worldwide (Armelagos and Cohen 1984; Cohen and Crane-Kramer 2007; Snoddy et al. 2017; Temple 2010), less attention has been given to the mechanisms of infectious disease transmission from one population to another where substantial levels of mobility (including migration) have been demonstrated. In these circumstances, interaction between two or more populations in so-called friction zones transpires (Bellwood and Oxenham 2008). Here genetic admixture and social transition occurs between foragers and farmers. Epidemiological transitions may follow population interactions, as subsistence transitions can cause micronutrient deficiencies, and contact between populations (as evidenced in MSEA) encourages the spread of infectious disease from one group to another. The identification of specific infectious diseases (such as leprosy, tuberculosis [TB], and treponemal disease) and the consequent epidemiological impact within the chronological, social, and environmental context of friction zones offers important information on human and pathogen co-evolution in the changing biosocial contexts of Southeast Asia over time. An example of the possible introduction of infectious disease with increased population interaction has been suggested in the case of leprosy and TB at a late Iron Age site in northeast Thailand (Tayles and Buckley 2004) but has not been explored in other regions or during periods of agricultural transitions in this region.

This article describes two cases of specific infectious and nutritional disease from the site of Man Bac in northern Vietnam and explores the social, biological, and ecological contexts that may have encouraged the spread of infectious disease during the Neolithic demographic transition in MSEA.

\section{Materials and Methods}

\section{The site}

Man Bac is a Phung Nguyen period early Neolithic habitation site with an associated cemetery located in Ninh Binh province in northern Vietnam, known for complex incised designs on pottery vessels, intricate stone craftwork, and interaction with Chinese Neolithic farming societies (Oxenham et al. 2011). Cultural material reflects both foraging and agricultural subsistence (Oxenham et al. 2011). Excavated in 1999, $2001,2004 / 5$, and 2007, the cemetery component of the 


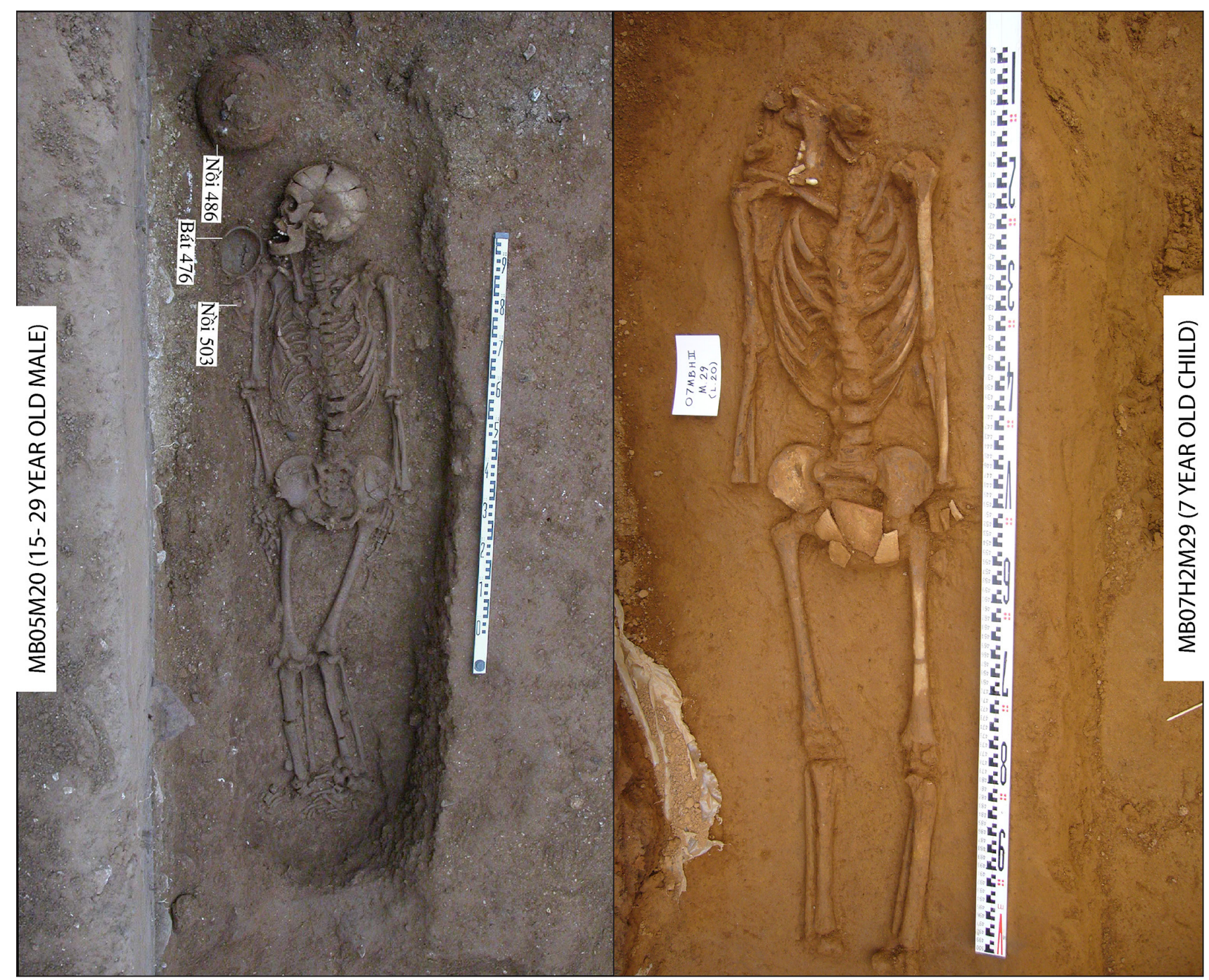

Figure 1. The burial position and associated artifacts of M20 (left) and M29 (right). Both individuals were buried extended and supine. The burials are in excellent skeletal condition with the exception of the cranium of M29, which was not present during excavation. (Image: M. Oxenham)

site consists of 101 individuals of exceptional skeletal preservation. Rib samples from four individuals from Man Bac have been dated to 1906-1523 cal B.C. (IntCal13, 95\% CI, with marine reservoir effect applied; Online Supplement). While insufficient collagen yield meant direct dates could not be derived from the two individuals of focus in this paper, all burials were found within a secure single stratigraphic layer (Oxenham et al. 2011). The burial layer was found below two occupation layers. Cultural material from all layers are contemporaneous, suggesting an association between the three layers. Charcoal from the occupation layers dates to 2016-1524 cal B.C. (95\% CI; Oxenham et al. 2011). As such, Man Bac is the only well-documented example of an early Neolithic settlement in Southeast Asia where local indigenous people coexisted with migrants from southern China who introduced agricultural practices to the region approximately 4,500 to 3,500 years ago (Bellwood and Oxenham 2008; Matsumura 2011a, 2011b).

It is not possible to estimate the population density of the Man Bac community, because the number of burials is not likely representative of the numbers in the living population and the full extent of the site has not been excavated. However, the Man Bac cemetery sample is characterized by a high fertility ratio and high rate of natural population growth, with $47.5 \%$ of individuals under the age of five years (McFadden et al. 2018). All burials, with the exception of three flexed inhumations, were in a supine extended position (Fig. 1), which is the normative pattern of burial at this time throughout Southeast Asia (Higham et al. 2011). Grave goods and ritual tooth removal (ablation) suggest age-based social hierarchy and affinal relationships 
that may have affected the distribution of resources within the community (Tilley and Oxenham 2016). Archaeological remains reveal a mixed or transitional subsistence based on foraging and agricultural practices, similar to other Phung Ngyuen period settlements. A diet of both terrestrial and aquatic protein resources is indicated by stable isotope collagen values, with more than $50 \%$ from aquatic resources (Oxenham et al. 2011). The presence of domesticated pig (Sus scrofa) dominates the zooarchaeological assemblage (R. K. Jones et al. 2019; Oxenham et al. 2011).

Today, Man Bac is situated approximately $25 \mathrm{~km}$ from the coast (Oxenham et al. 2011). However, given high sea levels in the mid-Holocene, Man Bac was likely much closer to the coast within an estuarine zone (Tanabe et al. 2006). The variety of faunal sources indicate that the inhabitants of Man Bac were exploiting a number of ecological zones, including forests, grasslands, lowlands, and marine and estuarine environments (Sawada et al. 2011; Toizumi et al. 2011). The site forms part of the Phung Nguyen complex, a series of sites found within the Ninh Binh region along the Red River Delta. The presence of contemporaneous pottery suggests extensive interaction between the sites farther inland along the river, as well as shared archaeological material with agricultural sites in southern China (Bellwood 2005; Nguyen 2008). The type site of Phung Nguyen is approximately $160 \mathrm{~km}$ from today's coastline, which represents the possible extent of interaction of farming settlements within northern Vietnam, although this site is dated to slightly later at around 1500 B.C. (Khoach 1980). Evidence of housing styles was not excavated at Man Bac. However, they may have been similar to other Phung Nguyen habitation sites where large houses on stilts (see Oxenham et al. [2015] for a discussion of built structures in the slightly later site of Rach Nui in southern Vietnam) appear to have been built, possibly for similar reasons as constructed in mountainous regions of Vietnam today, to keep out snakes and small animals (Khoach 1980).

Concerning the general health of people buried at Man Bac, previous research has demonstrated high levels of non-specific stress; $92.3 \%$ of males and $53.8 \%$ of females presented with cribra orbitalia, and $64.9 \%$ of the total assemblage presented with linear enamel hypoplasia of the incisors or canines (Oxenham et al. 2011). Forty-two percent of individuals had localized primary canine hypoplasia, which may be related to deficiencies of calcium, Vitamin A, or Vitamin D during gestation (McDonell and Oxenham 2014). Therefore, stress from parasitic, dietary, or infectious origin was commonplace during childhood for many of the individuals from Man Bac. The detailed paleopathology analysis of the total sample will be presented in forthcoming publications.

\section{Methods for age and sex estimation}

The age and sex of individuals from Man Bac were previously reported by Domett and Oxenham (2011). Adult sex estimations were based on standard methods for qualitative morphological estimates from the skull and pelvis (Acsádi et al. 1970; Buikstra and Ubelaker 1994; Phenice 1969). Non-adult age estimates were based on standards for the timing of dental calcification and eruption (Moorrees et al. 1963; Ubelaker 1999). Where teeth were not available for age assessment in non-adults, long bone lengths were compared to non-adults with dental estimates available, as well as to standards for long bone estimates in non-adults by Scheuer and Black (2000). Adult age estimation followed Suchey-Brooks standards for the pubic symphysis (Brooks and Suchey 1990).

\section{Recording methods for abnormal variation (pathological changes)}

Proliferative (lamellar and woven bone) and lytic lesions as well as bone deformities were recorded in the entire preserved skeleton. Lesions with the potential to contribute to diagnosis were also radiographed. A differential diagnosis was performed with the basis drawn from seminal literature in paleopathology (Brickley and Ives 2008; Lewis 2017; Ortner 2003; Snoddy et al. 2018; Weston 2012) as well as clinical literature concerning specific diseases (Hackett 1976; Jaffe 1972; Resnick 1995a). Lesions were characterized as diagnostic and suggestive of specific disease based on recommendations by Snoddy et al. (2018). A clinical basis for diagnosis of specific disease has also been championed by Mays (2012), Ortner (2011), Snoddy et al. (2020), Zuckerman et al. (2016), and others (for treponemal disease, Powell and Cook advocated such criteria in their 2005 book, as do Baker et al. [2020]). In the Snoddy et al. (2018) criteria, lesions are only considered to be diagnostic (D) if there is strong clinical basis or considerable body of paleopathological work supporting the diagnostic weight of the lesion. Lesions where there is no consensus in the clinical or paleopathological literature, but remain anatomically intuitive, were designated a suggestive (S) value. In addition, lesions that have been considered elsewhere as pathognomonic for disease are here scored as strongly diagnostic (SD) (after Brickley and Ives 2008). For a probable case of disease at least one strongly diagnostic and/or two diagnostic lesions are required (Brickley and Ives 2008; Snoddy et al. 2018). A possible case of disease requires a minimum of one diagnostic lesion and/or two suggestive lesions (Snoddy et al. 2018).

Clinically documented associated pathology was also considered in discussion of the disease expression, but it was not a primary deciding factor in the 
differential diagnosis due to their poor diagnostic strength in dry bone. These included generalized proliferative bone changes which can be caused by multiple diseases. (See Online Table S5 for summary of diagnostic strength of lesions.)

\section{Results}

The lesions at Man Bac were predominantly bilateral, symmetrical, and discrete and affected both the postcranial and cranial remains. As the focus of this paper is the identification of specific infectious disease at Man $\mathrm{Bac}$, the causes of the more generalized pattern of proliferative lesions at Mac Bac will be reported at a later date but are likely a result of a number of etiologies.

A total of seven individuals (10\%, 7/70) from Man Bac-two adults, two adolescents, and three childrenshare a similar skeletal pattern of diffuse proliferative new bone lesions consistent with systemic disease. Two of these seven individuals presented with widespread subperiosteal new bone, endosteal enlargements in the long bone shafts, and focal superficial lytic lesions within nodes of subperiosteal new bone (localized enlargements of subperiosteal new bone). These two individuals are the focus here due to the diagnostic potential of their lesions, with a brief discussion of a further five cases with lower diagnostic strength. A differential diagnosis was conducted on MB05 M20 and MB07 H2 M29, which includes systemic conditions known to produce lesions similar to those observed here: osteomyelitis (non-specific bone infection), leprosy, tuberculosis, brucellosis, mycosis, treponematosis, rickets/osteomalacia, and scurvy. A description of the bone pathology in these two individuals and a full differential diagnosis are presented. Detailed descriptions of lesions in all seven individuals are found in Online Table S5. Descriptions of skeletal lesions consistent with possible and probable treponemal disease in all affected Man Bac individuals can be found in Online Table S6.

\section{M20}

MB05 M20 (herein called M20) is a young adult male (15-29 years old). The individual was buried east to west in a supine position with three ceramic pots characteristic of the Phung Ngyuen period (Fig. 1). The skeleton is excellently represented, with all limbs, skull (and teeth), hands, and feet complete and 60\% representation of the ribs and vertebrae. The surfaces of the bones are in excellent condition. M20 presented with diffuse thick and remodeled new bone with endosteal enlargement of the entire shafts of the right humerus, tibiae, and fibulae (Fig. 2). Discrete nodes of new bone are present on the medial midshaft of the right tibia and on the distal third of both fibulae symmetrically. The new bone is present on the metaphyses and shafts of the tibiae and fibulae and the distal metaphysis of the right humerus. There are pathological pseudobowing deformities in the tibiae similar to bowing in a saber shin. While new bone is macroscopically only visible on the distal metaphysis of the right humerus, radiographs reveal endosteal enlargement of the entire shaft, suggesting prior osteoblastic activity that has since remodeled. Further discrete deposits of new bone can also be observed on the medial proximal left femur and medial and lateral proximal tibiae. Multiple superficial focal lytic lesions are present on the distal fibulae shafts, proximal right fibula, lateral metaphysis of the left humerus, and the lateral aspect of the left calcaneus. The focal lytic lesions of the fibulae are associated with discrete nodes of new bone and active new bone is observed around the margins of the lytic lesions. Two focal lesions of the right distal fibula have been damaged postmortem, so it is not possible to determine whether the lesions are superficial or extend into the medulla. However, a small focal superficial lesion is present adjacent to the larger two lesions (Fig. 2f), supporting the interpretation that the lesions with postmortem damage do not extend beyond the external cortical bone surface. The two focal lesions of the left distal fibula are clearly superficial, within a node of new bone and with smooth sclerotic margins (Fig. 2g).

No lytic or diffuse proliferative lesions were present on the cranial vault. Bilateral and symmetrical discrete deposits of remodeled new bone and abnormal cortical porosity are present on the external greater wings of the sphenoid bones, temporal bone squama, and posterior and anterior zygomatic bones. The lesions are clearly discrete and do not represent diffuse inflammatory changes in the skull. There are also porotic lesions across the ectocranium (frontal bone, occipital bone, and parietal bones medial to the temporal lines) consistent with porotic hyperostosis, although the diploe is not exposed so this cannot be confirmed. Medium-grade cribra orbitalia was also observed (after Stuart-Macadam 1985:392).

\section{M29}

MB07 H2 M29 (herein called M29) is a non-adult approximately seven years of age at death (Oxenham et al. 2011). M29 was buried supine; no clear grave goods were identified, but pottery sherds were present around the region of the sacrum (Fig. 1). The cranium was not present, and only the right side of the mandible (including teeth), remained. The individual's postcranial axial skeleton is very well preserved, but the hands and feet were virtually absent (with the exception of a single preserved metacarpal). There were some hardened soil concretions on the surfaces of the 


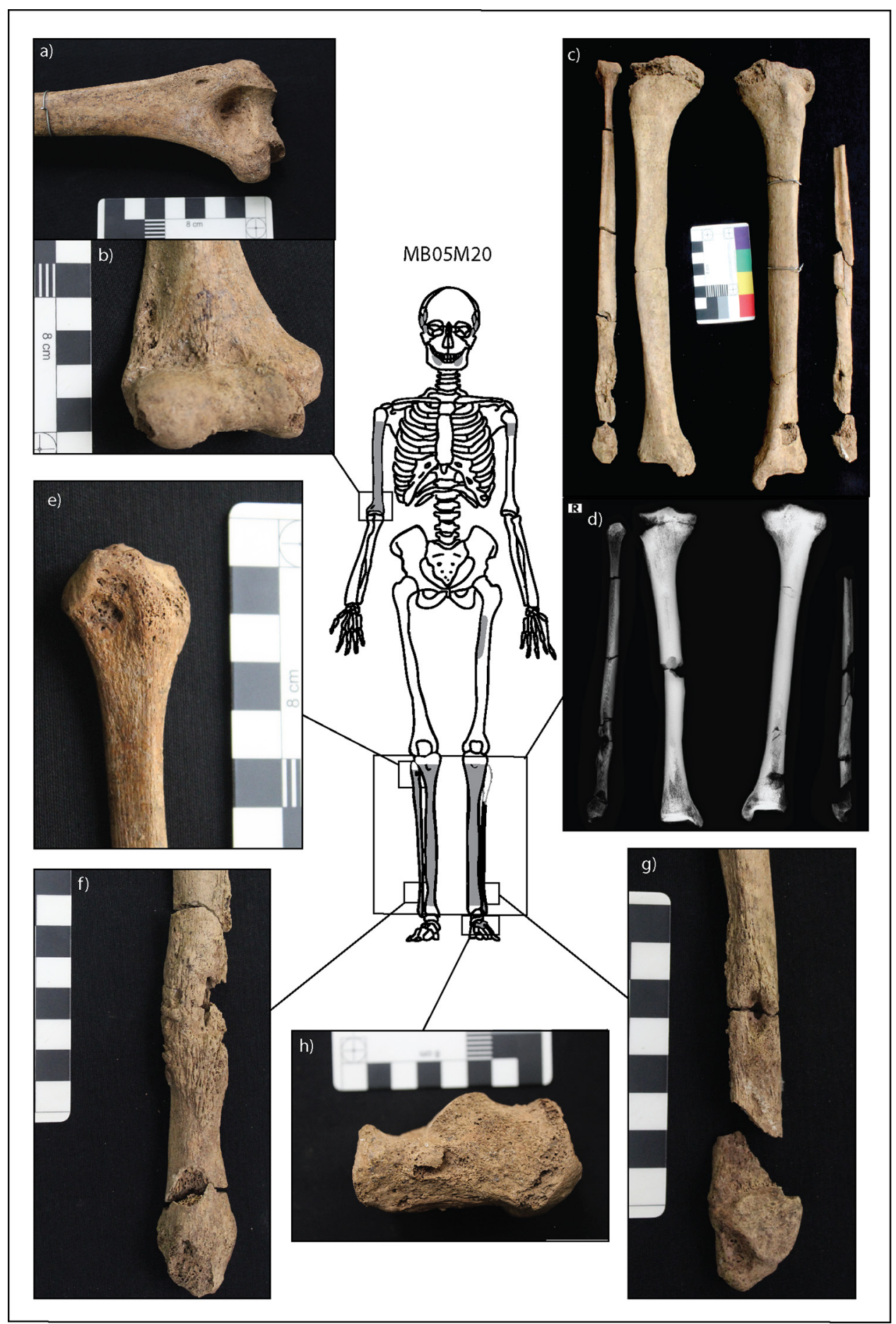

Figure 2. Expression of lesions related to infectious disease in M20. Preserved bones are outlined in black, with absent bones outlined in light gray. The skeletal extent of osteoblastic lesions is indicated by dark gray fill. (a) and (b) Superficial focal cavitations with smooth sclerotic margins not within distinct nodes of new bone on the anterior and posterior lateral epicondyle of the right humerus. (c) Remodeled cortical enlargements throughout the shafts of the tibiae with striated nodes of new bone on the distal fibulae. (d) Radiographs of the tibiae and fibulae: a distinct node of new bone with medullary intrusion is present on the medial middle shaft of the right tibia. The nodes of new bone of the distal fibulae are radiolucent due to the extent of pathological change to the internal cortex of the bone. (e) Superficial focal cavitation not within a distinct node of new bone on the proximal right fibula. (f) Two focal superficial cavitations on the lateral aspect of the right distal fibula within a distinct node of striated new bone. (g) Focal superficial cavitation on the medial aspect of the right distal fibula within a distinct node of striated new bone. (h) Focal superficial cavitation on the medial left calcaneal body, not within a distinct node of new bone. (Image: M. Vlok) 
long bones and vertebrae, but this was minimal. Animal gnaw and puncture marks were observed on some of the lower limb bones.

M29 presents with diffuse multi-layered new bone across the diaphyses of all limb bones bilaterally, and on the single preserved metacarpal (Fig. 3). Nodes of subperiosteal new bone are present at the midshafts of the right radius and ulna, proximal left ulna, entire shafts of tibiae, and distal fibulae. Multiple lytic lesions with sclerotic margins, observed radiographically, are present on the proximal left ulna, midshafts of the right radius and ulna, and inferior medial left clavicle. The lytic lesions of the midshaft of the right ulna and radius have some postmortem damage to the floor and margins. However, the preserved margins of the lesions indicate they did not penetrate the cortex. The lytic lesions on the distal fibulae do penetrate the cortex to the medullary canal. Radiographs also show well-remodeled proliferative new bone on the anterior crest of the tibiae, indicating so-called saber shin. A unilateral enlargement of the sternal end of the left clavicle without any macroscopic presence of thick subperiosteal new bone deposit is evident, and a thin cortex is appreciated from the radiograph. Symmetrical mixed active and remodeled new bone and abnormal cortical porosity is present in the supraspinous fossae of the scapulae. Although the cranium is absent, remodeled abnormal cortical porosity of the right coronoid process of the mandible is observed. Radiographically, all the long bones present with radiodense metaphyseal plates in association with zones of radiolucency in the metaphyseal region.

Deformity of some long bones is also present in M29. Symmetrical swellings of the distal metaphyses and slight cupping of the femora occur (Fig. 4c). There is slight bilateral medial "true" bowing of both tibiae confirmed by radiographs with slight posterior protrusion of proximal metaphyseal plates, suggesting depression and deformity (Fig. 4g). Further, there is lateral bowing of the proximal third of the humeral shafts, and depression and deformity of the metaphyses of the humeral heads (Fig. 4d).

\section{Discussion}

\section{Differential diagnosis}

The differential diagnosis of the types and skeletal pattern of the lesions in these Man Bac individuals included bone cancers, osteomyelitis, tuberculosis, brucellosis, mycosis, leprosy, and treponematosis. These diseases are included in the differential diagnosis due to the combination of proliferative and destructive lesions in the disease pathophysiology. The bone response to metastatic cancers may produce a combination of extensive subperiosteal and lytic response. However, these conditions are less likely to cause such widespread involvement of the skeleton as that observed here and are not known to cause multiple and widespread superficial cavitations (Ortner 2003:363-382, 503-544). Cancers such as multiple myeloma or Langerhan's cell histiocytosis ( $\mathrm{LCH})$, which can result in systemic multifocal destruction of the skeleton, most often appear as punched-out lytic lesions without sclerosis and can be ruled out (Ortner 2003:362, 377). M20 and M29 do not appear similar to a possible case of multiple myeloma or LCH identified by Domett and Buckley (2012) in pre-Angkorian Cambodia, and marginal sclerosis of the lytic lesions are rare and subperiosteal new bone deposits are not characteristic of these diseases (Ortner 2003:363, 377). Because bone cancer in archaeological contexts is extremely rare (Ortner 2003:363-382, 503-544), the presence of two individuals in the collection with similar bone lesions (M20 and M29) further demonstrates that cancer can be ruled out as a possible cause.

While subperiosteal and endosteal enlargement are non-specific inflammatory responses to various diseases and trauma (Weston 2012), the widespread and non-uniform nature of the enlargements in the Man Bac cases are more consistent with that of a systemic infection than metabolic or traumatic etiologies. The subperiosteal new bone lesions of metabolic disease tend to be uniform and symmetrical, unlike the majority of the lesions of M20 and M29 (Brickley and Ives 2008; Pitt 1995; Resnick 1995b; Snoddy et al. 2018). Furthermore, subperiosteal new bone from trauma is most often localized, also unlike that observed in M20 and M29 (Rana et al. 2009). However, some of the subperiosteal lesions in both M20 and M29 are symmetrical, and a metabolic etiology contributing to the overall expression of subperiosteal lesions in both individuals is not ruled out and is discussed further below.

Pyogenic osteomyelitis is a non-specific infection of the bone producing a characteristic suite of lesions of bone death from loss of blood supply (sequestrum), combining a lytic lesion (circular pus-draining cloaca) and a proliferative healing response (involucrum) (Ikpeme et al. 2010). The major causative agents are Staphylococcus or Streptococcus bacterial species, although other pathogens can infect bone (Acosta et al. 2004; Ikpeme et al. 2010). Initial transmission generally occurs through soft tissue infection of open wounds and, less frequently, secondary to respiratory, foodborne or water-borne diseases (Giaccai and Idriss 1952; Honda and McDonald 2009; Jaffe 1972:1015-1046; Miller et al. 1963; Vohra et al. 1997). The pathogenic agent enters the bone through the bloodstream and 


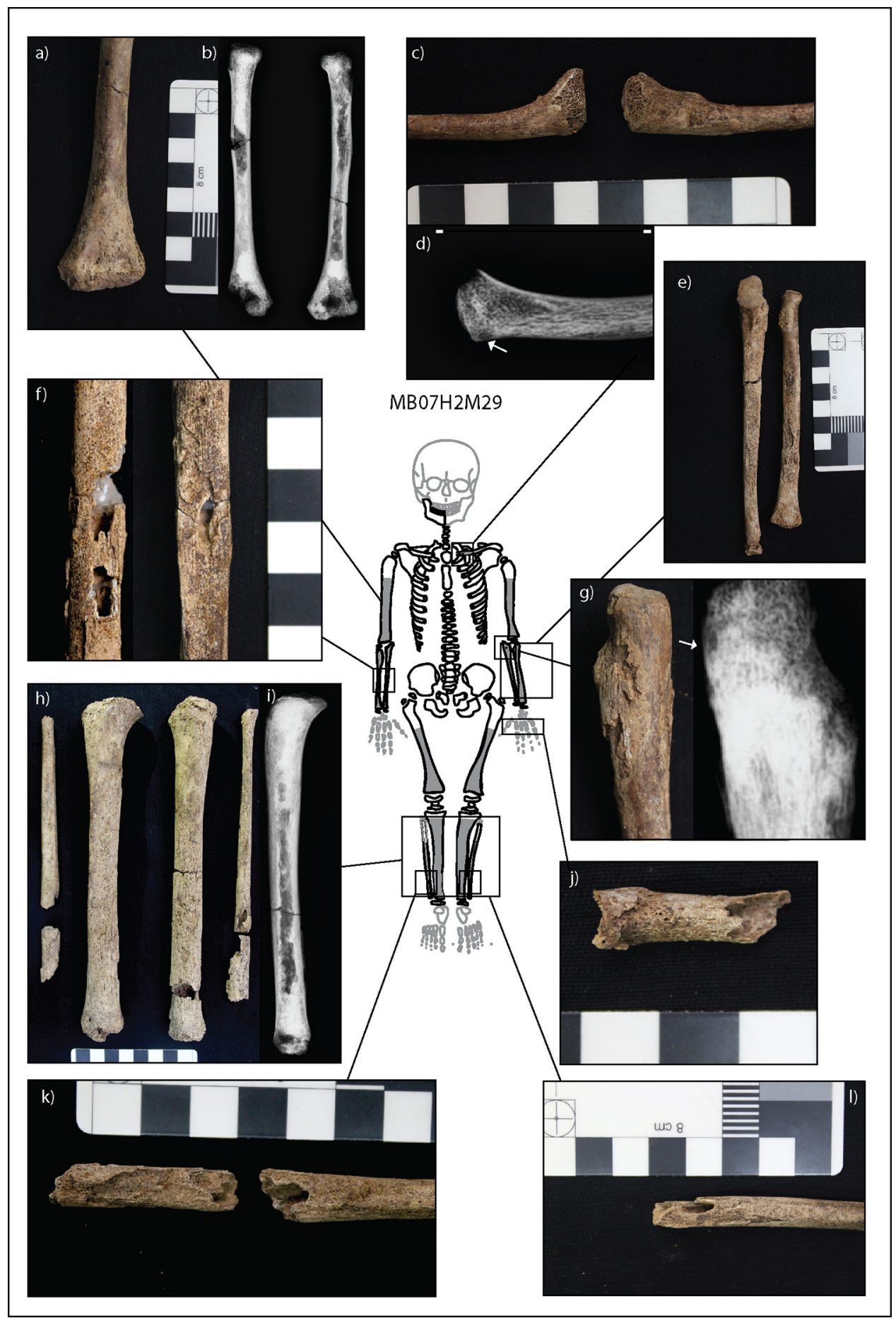

Figure 3. Expression of lesions related to infectious disease in M29. Preserved bones are outlined in black, with absent bones outlined in light gray. An undetermined metacarpal is also present but not demonstrated in the figure, as its skeletal position is unknown. The skeletal extent of osteoblastic lesions is indicated by dark gray fill. (a) Subperiosteal new bone deposit on the distal shafts and metaphyses of the humeri. (b) There are slight cortical enlargements visible on radiographs throughout the humeral shafts. (c) Remodeled enlargement of the medial left clavicle. The metaphyseal plate is bulging. (d) Radiographs do not demonstrate a distinct cortical enlargement of the left medial clavicle. The internal trabeculae appear radiolucent, and a distinct oval lytic lesion with a radiodense sclerotic margin is present on the inferior margin of the medial metaphysis. Some increased calcification is present on the medial metaphyseal plate. (e) Diffuse subperiosteal new bone deposit across the radii and ulnae. (f) Two oval cavitations within nodes of new bone on the midshafts of the right radius and ulna. While significant damage has occurred to the lesion floor, the margins of the lesion are preserved and indicate superficial cavitation. (g) Large node of new bone on the proximal left ulna. Radiographs demonstrate a small oval lytic lesion with sclerotic margins within the node. (h) Prolific subperiosteal new bone across the tibiae and fibulae. Fibular cortical enlargements are thickest toward the distal shaft. Note the rounded margins of the anterior shaft of the tibiae indicating saber shin deformity. (i) Radiograph of the right tibia demonstrating cortical enlargement of the anterior crest indicating saber shin. (j) An unknown metacarpal with significant postmortem damage. However, it is clear that the entire shaft of the metacarpal has undergone prolific pathological change indicative of dactylitis. The internal margins of the cortex are porous. (k) and (l) Focal cavitations of the right and left distal fibulae. Margins of the lesions are smooth and within nodes of new bone. The surrounding bone has undergone complete prolific pathological change with the internal cortex appearing porous. Osteoblastic lesions considered in the diagnosis of nutritional disease are presented in Figure 4. (Image: M. Vlok) 


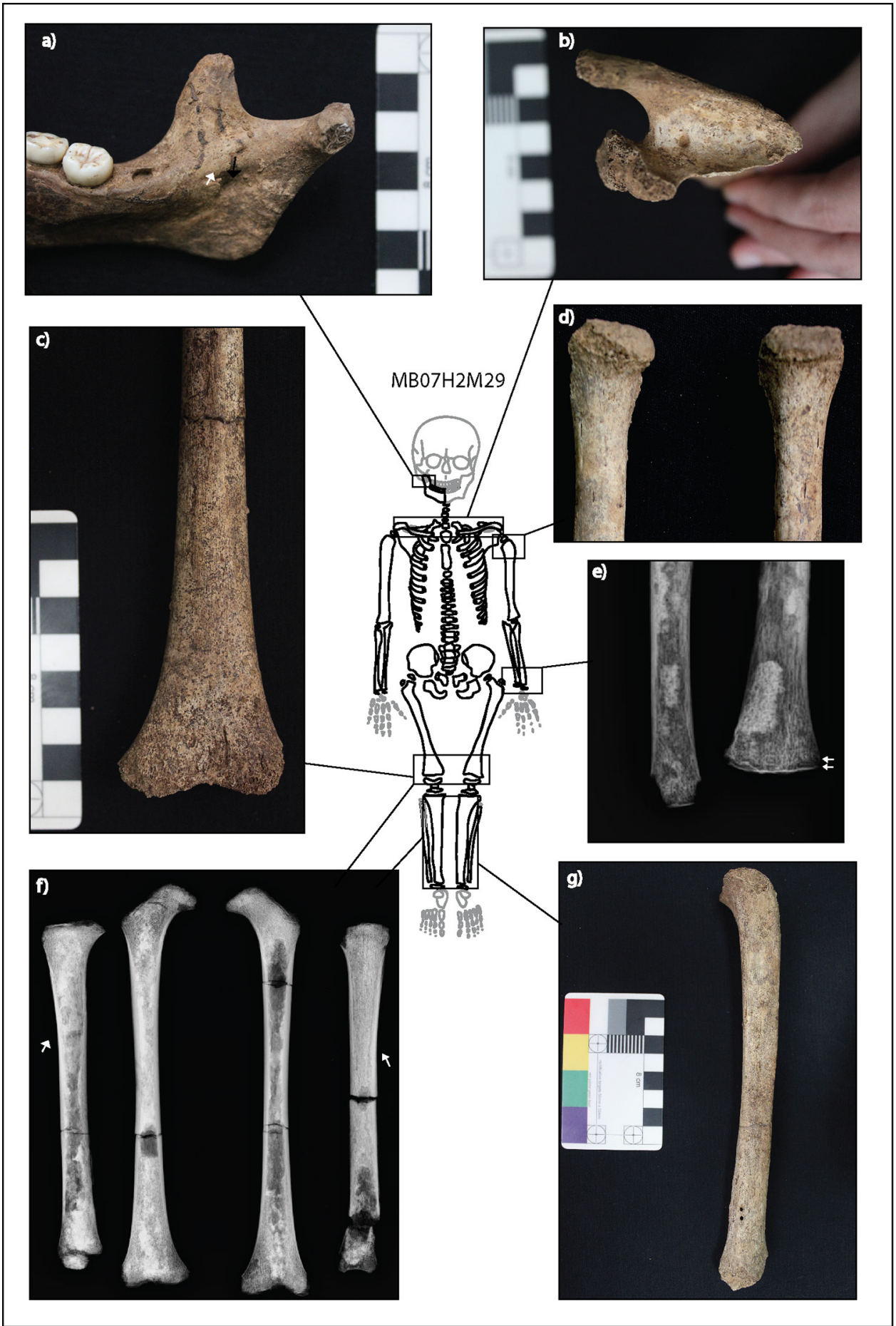

Figure 4. Expressions of lesions related to nutritional disease in M29. Preserved bones are outlined in black, with absent bones outlined in light gray. An undetermined metacarpal is also present but not demonstrated in the figure, as its skeletal position is unknown. The skeletal extent of osteoblastic lesions possibly related to nutritional disease is indicated by dark gray fill. (a) Mixed active and remodeled discrete deposit of subperiosteal new bone and abnormal cortical porosity medial to the coronoid process of the mandible. (b) Symmetrical mixed active and remodeled discrete deposit of subperiosteal new bone in the supraspinous fossa of the scapulae. (c) Bilateral swelling and slight cupping of the distal femur. (d) Depression of the humeral heads which are reminiscent of coxa vara deformities of the femoral heads (see Brickley and Ives 2008:102). (e) Trummerfeld (scurvy) line and white line of Frankle on the distal radius and ulna. These radiographic changes were identified in all metaphyses of long bones. (f) Slight medial bending deformities of the tibial shafts. (g) Posterior bending of the proximal metaphyseal plate of the tibia. (Image: M. Vlok) 
infiltrates through nutrient arteries (Jaffe 1972:10151020). Proliferation within bone generally begins in the metaphyseal region, eventually spreading to the cortex through the Haversian canals (Ikpeme et al. 2010; Jaffe 1972:1020). Osteomyelitis can result in nodes of new bone only, like treponemal disease (Hackett 1976:424). However, it is particularly diagnostic in its pyogenic form. Substantial deposits of subperiosteal new bone occur particularly in the long bones, resulting in a shell of new bone termed the involucrum (Ikpeme et al. 2010; Kharbanda and Dhir 1991). Disruption to blood supply by the involucrum results in bone death (sequestrum) (Ikpeme et al. 2010; Kharbanda and Dhir 1991). Finally, cloacae develop within the involucrum in order to drain pus that has accumulated within the medullary canal (Ikpeme et al. 2010; Kharbanda and Dhir 1991). Dactylitis, as observed in M29, is known to occur in osteomyelitis, but it is frequently associated with direct infection to the surrounding soft tissue due to trauma or localized infection (Jaffe 1972:1018). Osteomyelitis is rare in adults but can result from reoccurrence of infection from adolescence (Ortner 2003:187; Resnick and Niwayama 1995). However, the superficial focal cavitations on the external cortex as observed in the left fibula of M20 are unknown to occur in osteomyelitis and are incompatible with the pathophysiology of cloacae in pyogenic bone infection. While necrotic abscesses have been observed in osteomyelitis, they occur within the medullary canal and not the external cortex (Jaffe 1972:1020). Although two lesions in the distal fibulae of M29 penetrate to the medullary canal and are reminiscent of cloacae, such lesions have also been observed in cases of treponemal disease where gummatous lesions are associated with advanced endosteal enlargement (Hackett 1975). It is clear the entire bone of the fibulae shafts has been involved in this child with the inner cortex appearing porous. There is a lack of association of involucrum or sequestrae with the lytic lesions in M29, as would be expected with osteomyelitis, and more extensive proliferative new bone response also would be expected (Hackett 1976:92). Furthermore, it would be unusual for cloacae to occur symmetrically, such as observed in M29, as formation of cloacae is determined by the nature of the involucrum development and therefore they do not appear in predictable patterns (Jaffe 1972:1018; Roberts 2019:298). Systemic non-localized skeletal expression of both the lytic and proliferative lesions in M20 and M29 without focus of the infection in the metaphyseal regions of bone make osteomyelitis as the underlying cause extremely unlikely. However, given the non-specificity of osteomyelitis, particularly the non-pyogenic form, a secondary bacterial, viral, or fungal infection cannot be ruled out.
The Mycobacterium tuberculosis complex (MTBC) is a group of infectious slow-growing gram-positive bacteria that can cause granulomatous necrotizing abscesses throughout the entire body, including bone (Flynn and Chan 2001; Haque 1990; Knechel 2009). The MTBC consists of Mycobacterium strains that infect a number of mammalian primary hosts but can all cause infection of humans. These include: M. tuberculosis (humans), M. bovis (domestic livestock), M. canetti (humans), M. microti (voles, hyrax, llama, rarely humans), M. caprae (goats), M. pinnipedii (seals and sea lions, rarely humans), and M. africanum (humans) (Roberts 2012). The most common form is M. tuberculosis, which is primarily a respiratory disease affecting the lungs (De la Rua-Domenech 2006; World Health Organization 2013). M. tuberculosis is most often spread through air droplets from coughing, sneezing, and talking (Knechel 2009; World Health Organization 2013), whereas zoonotic forms such as $M$. bovis tend to spread to humans through ingestion of meat or dairy (De la Rua-Domenech 2006).

In its chronic form, tuberculosis can cause systemic granulomatous skeletal destruction with minimal new bone response, predominantly in regions of trabecular bone and articular surfaces, such as the vertebral bodies (Jaffe 1972:956; Key 1940; LaFond 1958; Ortner 2003:228). Therefore, bone destruction in tuberculosis most commonly affects the spine above all other skeletal elements, followed in frequency by involvement of the hip and knee joints (Jaffe 1972:956; LaFond 1958; Ortner 2003:228). In the most advanced form, destruction of the vertebral bodies results in collapse referred to as gibbus formation (or structural kyphosis) seen in Pott's disease, which has been considered pathognomonic for tuberculosis (Davidson and Horowitz 1970; Jaffe 1972:958-961; Turgut 2001). While circumferential deep focal destruction can occur in the long bones in tuberculosis, it is more characteristic of childhood tuberculosis, and even then it is focused in long bone ends rather than shafts (Lewis 2017:161; Ortner 2003:245; Teo and Peh 2004). Sclerotic margins of the superficial focal lesions on the external shafts of the long bones of M20 and M29 accompanied by cortical enlargement is not reminiscent of the destruction of tuberculosis, which, while chronic, elicits minimal remodeling of the lesion margins (Jaffe 1972:976). Proliferative new bone response is known to occur, particularly in the early stages of disease, as a systemic inflammatory response to the pathogen or due to psoas abscess formation adjacent to the lumbar spine, but is infrequently found in direct association with the destructive lesions in adults (Davidson and Horowitz 1970; Ortner 2003:232; Ridley et al. 1998). In the case of tuberculosis, dactylitis is rare but can occur in juveniles such as that observed in the single 
metacarpal of M29 (Teo and Peh 2004). However, in M29 the degree of expression is not severe and lacks the cystic destructive form more common to childhood tuberculosis (Lewis 2017:162; Teo and Peh 2004). As there is no evidence of spinal, trabecular, or joint involvement of which pathogens in the MTBC complex are selective for, tuberculosis is ruled out as a possible cause for the lesions in M20 and M29.

Brucellosis is a bacterial zoonotic disease commonly associated with animal husbandry. Human disease is mainly caused by four species of Brucella: $B$. abortus, B. suis, B. canis, and B. melitensis (Al-Shahed et al. 1994; Franco et al. 2007). The bacteria are transmitted mostly through consumption of animal products such as dairy, but they can be transmitted through skin lesions in circumstances of close contact with animals (d'Anastasio et al. 2011; Franco et al. 2007; Mehmet et al. 2002). The Brucella bacteria bind to cells of the mononuclear phagocyte system, a group of cells that includes bone marrow progenitors, blood monocytes, and macrophages found in hematopoietic regions of the body including in bone (Campbell et al. 1994; Hume 2006). Once chronic, brucellosis can affect the skeleton in focal or diffuse forms (Al-Shahed et al. 1994). Less has been described about the skeletal pathology of brucellosis than of tuberculosis, and questions remain about how to differentiate definitively between the two, and whether this is even possible in many cases (Al-Shahed et al. 1994). As is the case in tuberculosis, focal destruction of the spine is a primary characteristic of this disease (Al-Shahed et al. 1994). Brucellosis can cause widespread destruction of the skeleton, and skeletal involvement is common (Al-Shahed et al. 1994; Mehmet et al. 2002). Destructive lesions are often but not always accompanied by sclerotic reaction due to their slow development, which is not characteristic of tuberculosis (Roberts and Buikstra 2019: 421). Remodeling can result in the presence of parrot's beak osteophytes on the superior margin of the anterior vertebral bodies (Al-Shahed et al. 1994). While collapse of the spine can occur, it is unusual for the destruction to advance to the severity seen in tuberculosis (Roberts and Buikstra 2019). Similar to tuberculosis, osteolytic lesions develop in regions of hematopoiesis, including the hip, knee, and ankle joints (Al-Shahed et al. 1994; Mehmet et al. 2002). Unlike in tuberculosis, following the spine, the sacroiliac joint and knee are most commonly affected (Al-Shahed et al. 1994). For reasons similar to those stated in the consideration of tuberculosis, it is unlikely that brucellosis is responsible for the skeletal appearance of disease observed in M20 and M29. Although brucellosis is known to result in focal lesions with sclerotic response, superficial lesions of the external cortex, particularly in relation to cortical enlargements of long bone shafts, have not been observed in the pathophysiology of this disease.

Various fungal infections are known to result in skeletal involvement. Diseases including coccidioidomycosis, blastomycosis, histoplasmosis, aspergillosis, and cryptococcosis rarely infect the musculoskeletal system but are more common in immunocompromised individuals (Corr 2011). Transmission often occurs through open wounds or through the respiratory tract whereby hematogenous spread occurs (Corr 2011). Infection is more common in the spine, but it can occur in any region of the skeleton, particularly in regions of hematopoiesis (Corr 2011; Toone and Kelly 1956). For this reason there is a predilection for axial skeletal involvement (Taljanovic and Adam 2011). When long bones are involved the metaphyses are more commonly affected, with joints affected if destruction is extensive, at times resulting in septic arthritis (Taljanovic and Adam 2011). The pathological response is primarily in the form of focal punched-out or deep granulomatous osteolytic lesions with or without sclerotic margins (Corr 2011; R. C. Jones and Goodwin 1981; Taljanovic and Adam 2011; Toone and Kelly 1956). Proliferative new bone response to the extent observed in M20 and M29 has not been reported for mycotic infections. However, given the systemic inflammatory response observed in fungal infections such as coccidioidomycosis, the potential for subperiosteal involvement in mycotic infections cannot be ruled out (Corr 2011; Taljanovic and Adam 2011). Finally, clinical reports of skeletal mycotic infections describe lesions that tend to be unilateral and asymmetrical throughout the skeleton (R. C. Jones and Goodwin 1981; Taljanovic and Adam 2011; Toone and Kelly 1956). Given the predilection for the axial skeleton such as in the case of tuberculosis and brucellosis, destruction is associated with hematopoiesis in the skeleton, whereby deep osteolysis is more consistent with the pathophysiology of this disease group rather than superficial lytic lesions in the appendicular skeleton as observed in M20 and M29. The symmetrical lytic lesion pattern in the Man Bac individuals is also not consistent with clinical reports of mycosis. Mycosis is therefore ruled out as a possible cause.

Leprosy is a bacterial infection caused by Mycobacterium leprae or $M$. lepromatosis that affects the skin, nasal mucosa, and peripheral nerves (Eichelmann et al. 2013; Saonere 2011). The symptoms of the disease vary along a spectrum and are highly dependent on individual immune response (Eichelmann et al. 2013). Tuberculoid leprosy is a milder form that is often noncontagious, whereas lepromatous leprosy is more systemic, infectious, and results in more severe symptoms (Eichelmann et al. 2013; Saonere 2011). Major skeletal changes in leprosy involve naso-facial destruction 
with inflammatory pitting, and resorption of the terminal phalanges of the hands and feet secondary to loss of sensation from peripheral nerve or circulatory degeneration caused by the pathogen (MøllerChristensen 1961, 1978; Ortner 2003:264-265). Slow progression of resorption of the naso-palatal margins, including the anterior nasal spine, and alveolar process of the maxillary incisor area, with associated proliferative subperiosteal new bone and cortical pitting, are considered strongly diagnostic features of this disease (Møller-Christensen 1961, 1978; MøllerChristensen et al. 1952). While new bone can occur in leprosy, particularly in the lower legs, and skin granulomas can also occur, leprosy is not known to cause focal granulomatous-like lytic lesions of the long bones such as that observed in M20 and M29 (Faget and Mayoral 1944). Osteomyelitis secondary to peripheral nerve destruction in advanced stages of the disease is well documented, but as described above, the superficial lytic lesions of M20 and M29 are not characteristic of osteomyelitis (Faget and Mayoral 1944; Maas et al. 2002). The suite of cranial lesions observed in M20 is not characteristic of leprosy, as neither destructive lesions of the cranium nor proliferative or cortical pitting lesions of the nasal region were observed. Furthermore, no destructive changes to the preserved tubular hand and feet bones of M20 and M29 were observed. The absence of the cranium and the presence of only one metacarpal means leprosy cannot be ruled out as a co-morbidity in the case of the child. However, it is improbable that leprosy is responsible for lesions observed in both M20 and M29.

\section{Treponematosis}

Treponemal disease is a group of infections caused by a spirochete bacterium that primarily affects the skin but can also affect bones and other organs (Hook and Marra 1992). Four diseases, including yaws (Treponema pallidum pertenue), pinta (T. carateum), venereal syphilis (T. pallidum pallidum), and endemic syphilis (T. pallidum endemicum), have similar bacterium morphology and share similar pathogenesis (Hook and Marra 1992; Marks et al. 2014; Willcox 1974). Pinta is the only treponemal disease that does not affect bone (Willcox 1974). Each treponeme occupies a different ecological niche (Marks et al. 2014). For example, endemic syphilis is restricted to warm, arid regions of the world, whereas yaws thrives in subtropical and tropical regions (Willcox 1974). Yaws, pinta, and endemic syphilis are non-venereal treponemal diseases that are transmitted primarily by skin contact, whereas venereal syphilis has evolved to be spread primarily through sexual contact (Willcox 1974). A primary skin lesion forms at the site of inoculation within a few weeks of initial infection and subsequently resolves itself (Peeling and Hook 2006). If left untreated, the disease almost always progresses to a secondary phase. In the secondary phase, the skin rash reappears, becoming more diffuse and is associated with swelling of lymph nodes (lymphadenopathy) (Peeling and Hook 2006). The secondary phase is then followed by an asymptomatic latent phase, where the infection is contained within granulomas by the immune system (Hackett 1953b). Latency can last from three to 10 years beyond the initial infection (Hackett 1953b). Following the period of latency, except in the case of pinta, a tertiary stage begins, where necrosis of the granulomas occurs, resulting in gummatous lesions of skin, internal organs, and bones (Hackett 1953b; Powell and Cook 2005:15-51). Formation of the tertiary stage has been historically documented to occur in one in three untreated cases (Hackett 1953b). The tertiary stage is distinctive for its gross destruction of the face, skull, limbs, and, in the case of venereal syphilis, arterial vessels and organs (Hackett 1951; Peeling and Hook 2006). During the tertiary stage, secondary lesions stop forming (Hackett 1953b). While early treponemal lesions can heal within a few months, the late (tertiary stage) lesions can last for more than a year and leave permanent changes in bone (Hackett 1978).

These granulomatous, gummatous lesions are distinctive and specific to all treponemal diseases, and are universally accepted as strongly diagnostic in paleopathology (Harper et al. 2011; Ortner 2003:286). The so-called caries sicca lesions on the skull are the most well recognized lesions of the disease and are clinically and paleopathologically documented in all skeletal forms of treponemal disease (Hackett 1951:159-165, 1974; Sandison 1980). Gumma outside of the cranium can develop as focal lesions termed "superficial cavitations" within proliferative new bone on outer surfaces of long bones (Hackett 1976:362-396, 429-433). All tertiary lesions of treponemal disease are also associated with a sclerotic smoothing of the margins and base of the lesion (Hackett 1976:362-396, 429-433). Gross destruction of the palate and the nasal aperture can also occur (Hackett 1946). In the case of venereal syphilis, transplacental transmission, congenital syphilis, causes distinctive bone and dental deformations in infants and young children up until puberty (Jaffe 1972:908-910; Lewis 2017:176-177). Congenital forms are rarer in the endemic treponemes but have been reported in endemic syphilis from the Ramadi District of Iraq, and in yaws in central Java, Indonesia (Akrawi 1949; Csonka 1953; Engelhardt 1959). The three treponemes that affect bone cannot be distinguished by their skeletal expression (Harper et al. 2011).

As the above diseases are unlikely causes of the lesions, the presence of superficial cavitations within 
nodes of new bone in M20 and M29 strongly suggests that the etiology of the lesions expressed is treponematosis (Fig. 5). The presence of saber shin and dactylitis supports this diagnosis. We also note here that the lytic lesions and distinct nodes of new bone in M20 and M29 correspond with dissemination through lymph nodes argued by Buckley and Dias (2002) to be the primary form of noncranial dissemination of the Treponema pallidum spirochete into bone. Unilateral enlargement of the sternal end of the clavicle, as observed in M29, has been noted in cases of late-onset congenital syphilis (Dax and Stewart 1939; Frangos et al. 2011; Harper et al. 2011; Lewis 2017:179; Yang 1940). This so-called Higoumenakis sign presents as layers of proliferative new bone on the sternal end of the clavicle unilaterally (Frangos et al. 2011). The lack of macroscopic or radiographic trace of proliferative subperiosteal new bone or cortical enlargement on the sternal end of M29's left clavicle makes the identification of this pathology as a clear Higoumenakis sign difficult. However, a rationale for this is explained below in consideration of co-morbidity with nutritional stress.

To allow for standardization of diagnosis of treponemal diseases, we here present threshold criteria for the designation of possible and probable cases (Table 1). Standard criteria have been presented previously by Harper et al. (2011) using a five-point system for inclusion or exclusion of cases. This system attributes a score between 1 and 5 , dependent on the specificity of the lesion to treponemal disease. Non-specific lesions such as subperiosteal new bone deposit are classified as a score of 1 , and lesions specific to treponemal disease, such as gummatous lesions and late stage caries sicca of multiple skeletal elements, are provided a score of 5 . However, the authors do not give a minimum point score required for a sufficient diagnosis of treponemal disease in dry bone. The standardization presented here builds upon work by Harper et al. (2011) by introducing a "threshold approach" to diagnosis as recommended by Brickley and Ives (2008) for their criteria for diagnosis of scurvy, rickets, and osteomalacia and by Snoddy et al. (2018) for their criteria for scurvy diagnosis. As described above, we have employed the minimum criteria of one strongly diagnostic or two diagnostic lesions for a probable diagnosis of treponemal disease, which both of these cases demonstrate.

A recent review of global evidence for treponemal disease by Baker et al. (2020) includes a diagnostic protocol similar to the one presented here. The Baker et al. (2020) protocol divides lesions into three diagnostic strengths, consistent with treponemal infection but not diagnostic (C), strongly suggestive (ST), and pathognomonic $(\mathrm{P})$. The criteria presented by Baker et al. (2020) illustrate the consensus among paleopathologists to work toward standards of diagnosis of treponemal disease. Each of the two cases presented here would score 5 out of 5 using the Harper et al. (2011) criteria for diagnosis and would be scored as having pathognomonic lesions using the Baker et al. (2020) criteria, all consistent with probable diagnoses using the threshold criteria presented here.

\section{Nutritional disease}

Not all lesions of M20 and M29 are consistent with infectious disease only (Online Table S5). The discrete deposits of new bone and cortical porosity on the posterior and anterior aspects of the zygomatic bones, and the external greater wings of the sphenoid bones and the temporal bone squama in M20 are more consistent with repeated microtrauma and hematoma formation characteristic of scurvy and not of treponemal infection, where diffuse subperiosteal new bone across the face and cranium would be expected (Samarkos et al. 2011; Snoddy et al. 2018). This individual also has evidence of anemia in the form of cribra orbitalia and porotic hyperostosis of the ectocranial vault, which may be a consequence of parasitic, infectious, and/or nutritional stress in childhood. A synergistic relationship between infectious and nutritional diseases is well documented (Chan 2000; Larsen 1995; Mata 1975; Nussenblatt and Semba 2002; Pelletier et al. 1995; Roberts 2000; Roberts and Brickley 2018; Ruiz et al. 1994), and co-morbidity between these would not be unexpected at Man Bac given the biosocial context of subsistence transition occurring at the site (Larsen 1995; Oxenham et al. 2011).

Similar to M20, there are lesions present in M29 that are more likely to result from metabolic or developmental defects than infection (Fig. 4). As outlined above, various deformities are present in the long bones of M29. While it is possible that the swelling of the distal femora is a result of the infection, the combination of bending deformities, cupping, and swelling of distal ends of multiple long bones suggests alternative etiologies for these pathologies and is particularly indicative of a demineralization disorder, such as rickets (Brickley and Ives 2008:103-107). Interactions between infectious and nutritional diseases during childhood growth is an area of ongoing study in paleopathology, and it is possible that a combination of these factors caused the long bone bowing identified in M29. The described porotic and new bone lesions of the mandible and scapulae are all diagnostic macroscopic signs of scurvy (Snoddy et al. 2018). The radiographs also revealed ground-glass osteopenia, and Trummerfeld zones (radiolucent bands within the metaphyses) in association with white lines of Frankel 

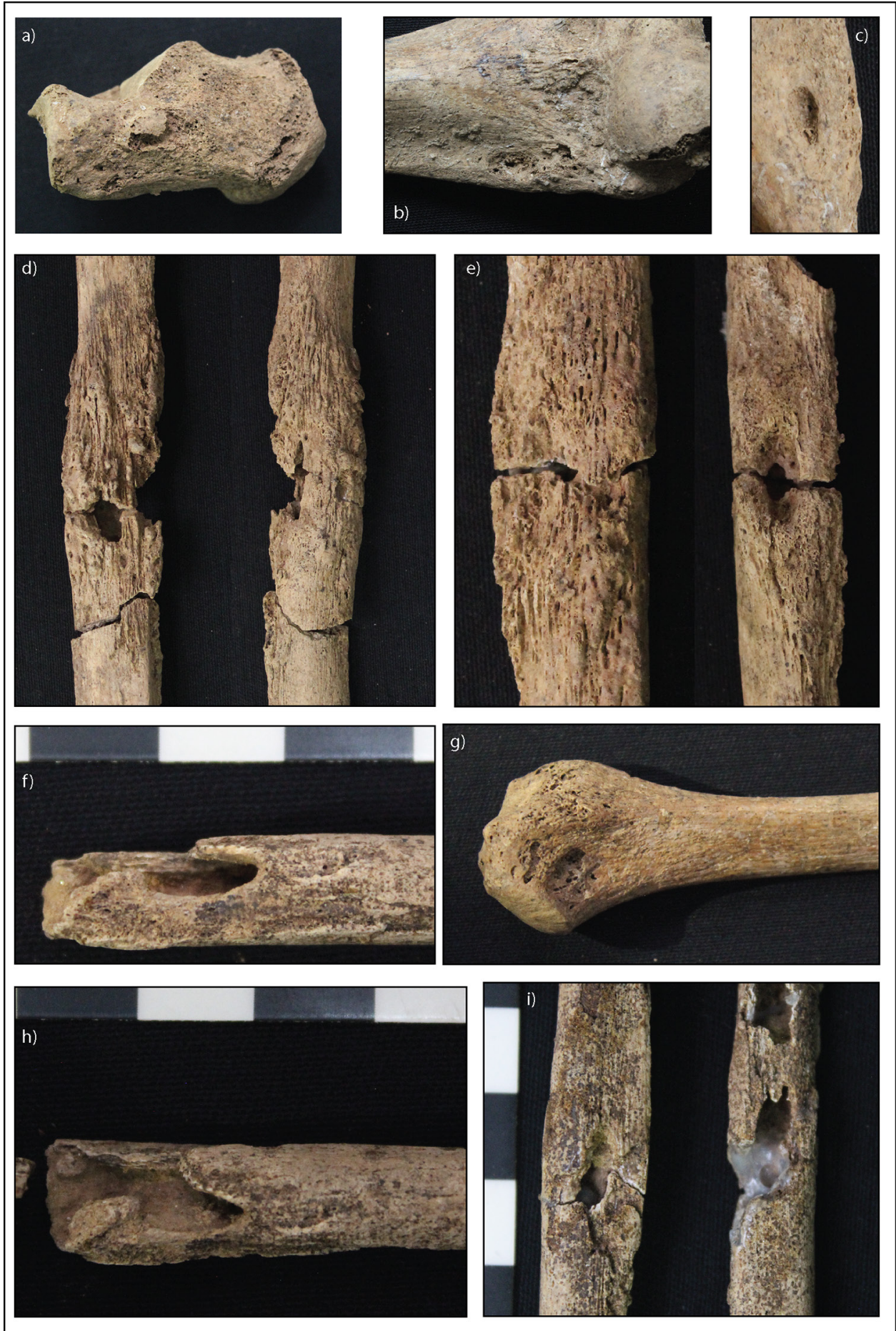

Figure 5. Strongly diagnostic and diagnostic macroscopic lesions for treponemal disease in M20 and M29. (a) Superficial focal cavitation of the medial left calcaneus (M20, diagnostic). (b) Superficial focal cavitation of the anterior lateral epicondyle of the right humerus (M20, diagnostic). (c) Superficial focal cavitation of the posterior lateral epicondyle of the right humerus (M20, diagnostic). (d) Superficial focal cavitations within a distinct node of new bone of the right distal fibular shaft (M20, strongly diagnostic). (e) Superficial focal cavitations within a distinct node of new bone of the right distal fibular shaft (M20, strongly diagnostic). (f) Focal cavitation of the right distal fibular shaft with sclerotic margins within a distinct node of new bone (M29, strongly diagnostic). (g) Superficial focal cavitation of the proximal right fibula (M20, diagnostic). (h) Focal cavitation of the right distal fibular shaft with sclerotic margins within a distinct node of new bone, same lesion as 5f. (M29, strongly diagnostic). (i) Focal cavitations of the right mid-ulnar and radial shafts with sclerotic margins within a distinct node of new bone (M29, strongly diagnostic). (Image: M. Vlok) 
Table 1. Diagnostic criteria for identification of treponematosis ( $\mathrm{SD}=$ strongly diagnostic, $\mathrm{D}=$ diagnostic, and $\mathrm{S}=$ suggestive). One $\mathrm{SD}$ lesion or two D lesions are required for diagnosis consistent with a probable case. One D lesion or two S lesions are required for diagnosis consistent with a possible case. Some lesions are provided for congenital cases and have been observed only in infants and children. The final column indicates which lesions were present in M20 and M29.

\begin{tabular}{|c|c|c|c|c|c|}
\hline Lesion & $\begin{array}{l}\text { Diagnostic } \\
\text { Strength }\end{array}$ & Differential Diagnosis & Clinical Reference & $\begin{array}{l}\text { Paleopathological } \\
\text { Reference }\end{array}$ & $\begin{array}{l}\text { Lesion } \\
\text { Present }\end{array}$ \\
\hline $\begin{array}{l}\text { Caries sicca sequence stages } 4-8 \text { : } \\
\text { circumvallate cavitation, radial scars, } \\
\text { serpiginous cavitation, nodular } \\
\text { cavitation, and caries sicca of the } \\
\text { ectocranium }\end{array}$ & SD & & $\begin{array}{l}\text { Hackett 1975, } \\
1976: 362-396\end{array}$ & Harper et al. 2011 & - \\
\hline $\begin{array}{l}\text { Gummatous lesions on any skeletal } \\
\text { element: focal superficial cavitations in } \\
\text { direct relation with nodes or expansions } \\
\text { (enlargements) of new bone }\end{array}$ & $\mathrm{SD}$ & & $\begin{array}{l}\text { Hackett } 1975, \\
1976: 429-433\end{array}$ & Harper et al. 2011 & $\begin{array}{l}\text { M20 } \\
\text { M29 }\end{array}$ \\
\hline Hutchinson's incisors (congenital) & SD & Normal morphology & $\begin{array}{l}\text { Hackett 1976:441; } \\
\text { Pessoa and Galvão } \\
\text { 2011; Stokes and } \\
\text { Gardner } 1923\end{array}$ & $\begin{array}{l}\text { Harper et al. 2011; } \\
\text { Hillson et al. 1998; } \\
\text { Lewis 2017:179 }\end{array}$ & - \\
\hline Moon's Molars (congenital) & $\mathrm{SD}$ & Growth disruption & Hackett 1976:441 & $\begin{array}{l}\text { Harper et al. 2011; } \\
\text { Hillson et al. 1998; } \\
\text { Lewis 2017:179 }\end{array}$ & - \\
\hline $\begin{array}{l}\text { Congenital syphilis (Caffey's) triad: } \\
\text { osteochondritis, bilateral thick periosteal } \\
\text { reaction of the long bones, and osteomy- } \\
\text { elitis of metaphyseal ends (early } \\
\text { congenital) }\end{array}$ & $\mathrm{D}$ & $\begin{array}{l}\text { Non-specific osteomyelitis, } \\
\text { infantile cortical hyperostosis, } \\
\text { Paget's disease }\end{array}$ & $\begin{array}{l}\text { Caffey 1939; Jaffe } \\
\text { 1972:910 }\end{array}$ & Lewis $2017: 178$ & - \\
\hline $\begin{array}{l}\text { Caries sicca sequence stages 1-3: clustered } \\
\text { pits, confluent clustered pits, focal } \\
\text { superficial cavitation of the ectocranium } \\
\text { or focal superficial cavitation of the } \\
\text { cortex of long bones not within a distinct } \\
\text { node or expansion (enlargement) }\end{array}$ & $\mathrm{D}$ & $\begin{array}{l}\text { Mycosis, tuberculosis, } \\
\text { Langerhans's cell histiocytosis, } \\
\text { multiple myeloma, and other } \\
\text { metastatic neoplasms }\end{array}$ & $\begin{array}{l}\text { Hackett } 1975, \\
1976: 362-396\end{array}$ & & M20 \\
\hline $\begin{array}{l}\text { Gross rhinomaxillary and palatal } \\
\text { destruction (gangosa) }\end{array}$ & $\mathrm{D}$ & $\begin{array}{l}\text { Leprosy, tuberculosis, mycosis, } \\
\text { destructive neoplasms, trauma, } \\
\text { leishmaniasis }\end{array}$ & $\begin{array}{l}\text { Fiumara and Lessell } \\
\text { 1970; Hackett } \\
\text { 1951:164-168, 1975, } \\
\text { 1976:399-401 }\end{array}$ & Lewis 2017:175 & - \\
\hline $\begin{array}{l}\text { Wimberger's corner sign (congenital): } \\
\text { bilateral widening band of decreased } \\
\text { calcification of the metaphyses leading to } \\
\text { destruction }\end{array}$ & $\mathrm{D}$ & $\begin{array}{l}\text { Non-specific osteomyelitis, } \\
\text { trauma, scurvy }\end{array}$ & $\begin{array}{l}\text { Brackett and } \\
\text { Standley 2019; } \\
\text { Rasool and } \\
\text { Govender } 1989\end{array}$ & $\begin{array}{l}\text { Harper et al. 2011; } \\
\text { Lewis 2017:178 }\end{array}$ & - \\
\hline Mulberry (Fournier's) molars & $\mathrm{D}$ & $\begin{array}{l}\text { Mercury use, growth } \\
\text { disruption }\end{array}$ & & $\begin{array}{l}\text { Harper et al. 2011; } \\
\text { Hillson et al. 1998; } \\
\text { Lewis 2017:179 }\end{array}$ & - \\
\hline $\begin{array}{l}\text { Thick periosteal new bone deposition and } \\
\text { exostoses on the maxillae (goundou) }\end{array}$ & $\mathrm{S}$ & $\begin{array}{l}\text { Scurvy, osteomyelitis, leprosy, } \\
\text { infantile cortical hyperostosis, } \\
\text { Paget's disease, genetic anemias }\end{array}$ & & $\begin{array}{l}\text { Buckley 2016:30; } \\
\text { Harper et al. 2011; } \\
\text { Lewis 2017:175 }\end{array}$ & - \\
\hline $\begin{array}{l}\text { Higoumenakis sign: unilateral enlarge- } \\
\text { ment of the sternal end of the clavicle } \\
\text { (congenital) }\end{array}$ & $\mathrm{S}$ & $\begin{array}{l}\text { Trauma, non-specific } \\
\text { osteomyelitis, normal variant }\end{array}$ & $\begin{array}{l}\text { Dax and Stewart } \\
\text { 1939; Yang } 1940\end{array}$ & $\begin{array}{l}\text { Frangos et al. 2011; } \\
\text { Harper et al. 2011; } \\
\text { Lewis 2017:179 }\end{array}$ & M29 \\
\hline $\begin{array}{l}\text { Saber shin (pseudobowing of the tibia } \\
\text { without bowing of the medullary canal) }\end{array}$ & S & $\begin{array}{l}\text { Leprosy, osteomyelitis, various } \\
\text { benign and malignant bone } \\
\text { tumors, Paget's disease, } \\
\text { hyperflourosis }\end{array}$ & Hackett 1951:28 & Harper et al. 2011 & $\begin{array}{l}\text { M20 } \\
\text { M29 }\end{array}$ \\
\hline $\begin{array}{l}\text { Boomerang leg: true tibial bowing with } \\
\text { bowing of medullary canal (until } \\
\text { adolescence) }\end{array}$ & S & $\begin{array}{l}\text { Rickets, skeletal dysplasias, } \\
\text { osteogenesis imperfecta, } \\
\text { fracture }\end{array}$ & & $\begin{array}{l}\text { Harper et al. 2011; } \\
\text { Lewis 2017:175 }\end{array}$ & - \\
\hline $\begin{array}{l}\text { Dactylitis (subperiosteal new bone } \\
\text { enlargement of the hand and feet bones) }\end{array}$ & S & $\begin{array}{l}\text { Tuberculosis, non-specific } \\
\text { osteomyelitis, genetic anemias }\end{array}$ & $\begin{array}{l}\text { Hackett 1951:30; } \\
\text { Rasool and } \\
\text { Govender } 1989\end{array}$ & $\begin{array}{l}\text { Harper et al. 2011; } \\
\text { Lewis 2017:178-179 }\end{array}$ & $\begin{array}{l}\text { M20 } \\
\text { M29 }\end{array}$ \\
\hline $\begin{array}{l}\text { Charcot's joint (resorption of weight } \\
\text { bearing joints) }\end{array}$ & $\mathrm{S}$ & $\begin{array}{l}\text { Septic arthritis, diabetes, } \\
\text { osteoarthritis, syringomyelia, } \\
\text { tuberculosis }\end{array}$ & $\begin{array}{l}\text { Hackett 1976; Johns } \\
\text { 1970; Sequeira } 1994\end{array}$ & $\begin{array}{l}\text { Harper et al. 2011; } \\
\text { Lewis 2017:179 }\end{array}$ & - \\
\hline
\end{tabular}


Table 1. (continued).

\begin{tabular}{|c|c|c|c|c|c|}
\hline Lesion & $\begin{array}{l}\text { Diagnostic } \\
\text { Strength }\end{array}$ & Differential Diagnosis & Clinical Reference & $\begin{array}{l}\text { Paleopathological } \\
\text { Reference }\end{array}$ & $\begin{array}{l}\text { Lesion } \\
\text { Present }\end{array}$ \\
\hline $\begin{array}{l}\text { Opera glass fingers: diaphyseal tapering } \\
\text { of the bone }\end{array}$ & S & $\begin{array}{l}\text { Leprosy, rheumatoid arthritis, } \\
\text { syringomyelia, diabetes, } \\
\text { osteomyelitis, erosive } \\
\text { osteoarthritis }\end{array}$ & $\begin{array}{l}\text { Hackett 1951:153- } \\
\text { 154; B. S. Jones 1972; } \\
\text { Swezey et al. } 1972\end{array}$ & Ortner 2003:277 & - \\
\hline $\begin{array}{l}\text { Radiographic: saw tooth appearance of } \\
\text { metaphyseal ends or macroscopic } \\
\text { symmetrical destruction of metaphyses } \\
\text { attributed to osteochondritis (early } \\
\text { congenital) }\end{array}$ & $S$ & $\begin{array}{l}\text { Rickets, scurvy, trauma, } \\
\text { tuberculosis }\end{array}$ & $\begin{array}{l}\text { Jaffe 1972:910-912; } \\
\text { Rasool and } \\
\text { Govender } 1989\end{array}$ & $\begin{array}{l}\text { Harper et al. 2011; } \\
\text { Lewis 2017:178 }\end{array}$ & - \\
\hline $\begin{array}{l}\text { Thick deposit of mixed active and } \\
\text { remodeled new bone on the long bones, } \\
\text { thickest at the midshaft (congenital), or } \\
\text { long bone endosteal nodes or expansions } \\
\text { (enlargements) with medullary canal } \\
\text { intrusion }\end{array}$ & $\mathrm{S}$ & $\begin{array}{l}\text { Paget's disease, non-specific } \\
\text { osteomyelitis, metastatic bone } \\
\text { tumors, tuberculosis }\end{array}$ & $\begin{array}{l}\text { Hackett 1951, 1975, } \\
\text { 1976:411-433 }\end{array}$ & $\begin{array}{l}\text { Harper et al. 2011; } \\
\text { Lewis } \\
\text { 2017:178-180 }\end{array}$ & $\begin{array}{l}\text { M20 } \\
\text { M29 }\end{array}$ \\
\hline Saddle nose (congenital) & $S$ & $\begin{array}{l}\text { Leprosy, trauma, non-specific } \\
\text { osteomyelitis }\end{array}$ & $\begin{array}{l}\text { Fiumara and Lessell } \\
\text { 1970; Pavithran } 1987\end{array}$ & $\begin{array}{l}\text { Harper et al. 2011; } \\
\text { Lewis 2017:177 }\end{array}$ & - \\
\hline High palatal arch (congenital) & S & $\begin{array}{l}\text { Various congenital deformities, } \\
\text { including Turner's syndrome } \\
\text { and Klippel-Feil syndrome }\end{array}$ & Pavithran 1987 & Lewis 2017:177 & - \\
\hline
\end{tabular}

(radiodense lines on the metaphyseal plates of the long bones) (Fig. 4), which are further diagnostic signs of Vitamin C deficiency (Brickley and Ives 2008; Snoddy et al. 2017, 2018).

The likelihood of co-morbidity of treponemal disease with nutritional deficiency in M29, including scurvy as well as deficiency of hormones, minerals, and/or vitamins related to the mineralization process (Vitamin D, calcium, phosphorus, and/or parathyroid hormones), may be causing the concurrent thinning of cortices impacting the visibility of a clear Higoumenakis sign of congenital syphilis. As gummatous lesions usually form within localized nodes of new bone, the presence of a small lytic process on the medial end of M29's left clavicle may suggest a well-remodeled new bone deposit in a child with a high bone turnover rate also undergoing nutritional stress. The presence of a congenital expression of treponemal disease at Man Bac is then possible. In summary, M29 probably suffered from tertiary treponemal disease in association with multiple nutrient deficiencies affecting both osteoid formation and mineralization at various points in the child's lifetime. In light of more definitive evidence of nutritional stress in M29, an argument could be made for a co-morbidity of treponemal disease and Vitamin C deficiency in M20 as well.

\section{Possible treponemal disease?}

Lesions in five other individuals are also consistent with treponemal disease. However, the skeletal expression of their lesions does not provide enough diagnostic strength to allow a probable diagnosis. MB05 M5 is an infant approximately 18 months of age with endosteal enlargement of the long bones associated with superficial lytic lesions. While the radiographs demonstrate a superficial focal sclerotic response in the distal metaphysis of the left humerus and superior acromial end of the clavicle, these lesions are small (lesion is $3.9 \times 1.7 \mathrm{~mm}$ on humerus and $3 \times 3 \mathrm{~mm}$ on clavicle), impeding confidence that these lesions are superficial focal cavitations as described by Hackett (1976:429433). MB05 M29 is a middle-aged adult male with dactylitis and diffuse new bone in the forearms and legs associated with endosteal enlargements. Two focal superficial lesions with sclerotic response are present on the medial distal right fibula. However, these lesions are not within a distinct node of new bone and therefore do not strictly fit the definition of superficial cavitation by Hackett. A further three individuals present with endosteal nodes/enlargements, and/or dactylitis, which are also consistent with treponemal disease (see Online Table S6). All lesions follow a postcranial pattern of lymphatic dissemination consistent with treponemal disease (Buckley and Dias 2002).

\section{Pathophysiology of treponemal disease in M20 and M29}

The presence of gummatous lesions in M20 and M29 is strongly diagnostic for treponemal disease in this early Neolithic community and, therefore, is sufficient evidence for pre-Columbian treponemal disease outside of the Americas, and represent the oldest cases in 
the Asia-Pacific region. The presence of a possible $\mathrm{Hi}$ goumenakis sign in M29 attributed to the late-onset congenital form of treponemal disease does suggest the possibility of transplacental transmission in this case. Transplacental transmission of yaws has been known to occur, albeit rarely (Engelhardt 1959). Children infrequently develop gummatous lesions, but they also have been documented to occur in yaws (Hackett 1951). Given the age of M20 it is possible that initial infection occurred in late childhood to adolescence, which is epidemiologically consistent with all treponemal diseases.

\section{Which treponemal disease was present in Neolithic Man Bac?}

We offer no attempt to diagnose which treponemal disease is responsible based solely on skeletal expression. Discussion on the uniformity of skeletal lesions of different treponemes has been dealt with elsewhere (Buckley and Dias 2002). However, the epidemiological, social, and environmental contexts of the disease do allow some discussion on the treponeme responsible. Climatically, Vietnam is within latitudinal boundaries where yaws has been historically documented (Mitjà et al. 2013). Prior to the eradication attempts of yaws by the World Health Organization in the 1950s, yaws was endemic to Vietnam, and reports as late as the 1990s demonstrate a recent history of the disease in the region (Meheus and Antal 1992). With consideration of all possible and probable cases at Man Bac, it is clear the lesions are predominantly in non-adults, with only two adults presenting lesions consistent with treponematosis and only one of these with strongly diagnostic lesions (Online Table S6). The epidemiological distribution in terms of age does suggest a non-venereal form such as yaws, where initial infection most often occurs between the ages of two and 15 years (Mitjà et al. 2013). Therefore, yaws is a possible candidate for the treponemal disease present at Man Bac. However, the climate of this region is marginal for the successful maintenance of yaws in a community. Yaws thrives in regions with average yearly temperatures of $27^{\circ} \mathrm{C}$ but can persist in areas of, at minimum, $21^{\circ} \mathrm{C}$ yearly average temperature (Hill 1953). While northern Vietnam fits into this range, in regions where temperatures are not consistent year round, yaws is even less likely to thrive (Hill 1953). In January the minimum average temperature in northern Vietnam is $12^{\circ} \mathrm{C}$, and $14.3^{\circ} \mathrm{C}$ specifically for Ninh Binh province where Man Bac is situated (Oxenham et al. 2011). The temperature during the early Neolithic of Vietnam may have been slightly elevated compared to the present day due to the termination of the midHolocene Thermal Maximum at around 3000 B.C., which was marked by higher temperatures and rainfall (Oxenham et al. 2018). While there are no historic reports of endemic syphilis in the region, northern Vietnam becomes cold and dry during the winter months, which is more suitable for the endemic form. In summary, the ecological and climatic context of Man Bac allowed for the presence of all of the treponemal conditions. However, given the age of the site and epidemiology in regard to the ages of affected individuals, it is more likely a non-venereal rather than venereal form.

\section{Social and biological conditions promoting treponemal disease at Man Bac}

The ecological and social contexts of Man Bac fostered an environment that was advantageous to the spread of non-venereal treponemal disease in the community. Agricultural transitions such as that which occurred at Man Bac have been universally documented to have resulted in epidemiological transitions as farming practices encouraged sedentism, population growth, and increased susceptibility to infection due to nutritional stress (Armelagos and Cohen 1984; Cohen and Crane-Kramer 2007; Larsen 2006). In northern Vietnam this subsistence change may have led to different epidemiological pressures in the communities with no distinct decline in health, as pre-Neolithic sedentary foragers also had high disease burdens (Oxenham et al. 2018). Signs of multi-nutrient deficiency throughout the life of M20 and M29 is further supported by considerably high levels of stress identified in other dental and skeletal evidence from the site (McDonell and Oxenham 2014; Oxenham and Domett 2011).

Coastal habitations such as prehistoric Man Bac have been associated with higher yaws incidence in historical contexts due to the abundance of water and vegetation, increasing population density (Hackett 1953a:135; Kazadi et al. 2014). Furthermore, preindustrialized agricultural communities have also been associated with increased incidence of yaws (Guimarães 1953; Hackett 1953a:135). The coastal region is also slightly warmer and more humid than inland northern Vietnam and therefore more conducive to the spread of yaws (Hill 1953).

The increase in fertility and population growth at Man Bac was likely associated with an increase in the number of infants and children within the community, who are known to be the primary transmitters of yaws (McFadden et al. 2018; Mitjà et al. 2013). Given the age-based hierarchy, possible relocation of resources to older individuals in the community may have promoted malnutrition in younger individuals, further encouraging disease transmission in children (Hill 1953; Oxenham et al. 2011). A degree of social 
group cohesiveness may have further encouraged the transmission of a non-venereal form of treponematosis spread through close skin contact. The presence of a profoundly disabled individual with quadriparesis following Klippel-Feil syndrome, who required continuous and intensive care, highlights that the community was one in which individuals were highly cooperative (Oxenham et al. 2009; Tilley and Oxenham 2011).

\section{Origins of treponemal disease at Man Bac}

It is not possible at this point to determine confidently whether treponemal disease was introduced by the farmers from southern China. However, the spread of treponemal disease into MSEA with migrant farmers during the Neolithic is plausible when considering the extent of the migration and the sedentary agricultural contexts they brought with them (Bellwood and Oxenham 2008). There is no archaeological evidence for contact with other groups apart from southern Chinese farmers outside of MSEA at this time. Admixture with indigenous foragers in northern Vietnam may have enabled further transmission of treponemal disease throughout MSEA, although currently no further evidence for prehistoric treponemal disease exists in Southeast Asian skeletal collections. While we recognize that absence of evidence is not evidence of absence, and a deep antiquity of treponemal disease in MSEA is possible prior to the agricultural transition, there is no identification of human-to-human transmissive diseases (such as tuberculosis, treponematosis, or leprosy) prior to this time in MSEA despite intensive bioarchaeological research in the region (Buckley and Oxenham 2016). The evidence of infectious disease in MSEA considerably increases from the Bronze and Iron Ages (Oxenham et al. 2005; Tayles and Buckley 2004). If the treponemal disease at Man Bac is in fact yaws, the route of transmission throughout the continent would be restricted to tropical and subtropical zones. Although Man Bac is positioned at the present-day upper geographical limit of the survival of yaws, documented cases of yaws existed in southern China and Taiwan prior to worldwide eradication attempts where the climate is similar to northern Vietnam's (Hill 1953). In light of pre-eradication, clinical evidence of yaws in this region, a possible origin for the spread of treponemal disease into MSEA from farmers originating in southern China from approximately 4,000 years ago is plausible. Given the presence of treponemal disease at Man Bac, regional interactions throughout the Red River delta also present possible routes of transmission to and from other Phung Nguyen sites where archaeological material indicates contact with agricultural groups of southern China
(Khoach 1980; Nguyen 2008). The implications of migration and human population interaction on the potential spread of treponemal disease into northern Vietnam is an area for further research, particularly with regard to the broader context of the timing of the introduction of treponemal disease into MSEA. Further investigation of existing and newly excavated skeletal assemblages in southern China and MSEA may provide further insight into the origins and antiquity of this disease within the region.

It can be hypothesized that, with the demographic and subsistence transition resulting in nutritional instability, and possibly the introduction of new infectious diseases with migration, the social and environmental contexts of Man Bac were suitable for the spread of treponematosis. The high rate of natural population increase at Man Bac was likely fueled by the supplementation of agricultural foods, enabling larger groups to thrive, increasing the number of individuals in the community, and further encouraging the spread of treponematosis (McFadden et al. 2018). The identification of two cases of probable tertiary treponemal disease in a northern Vietnamese Neolithic community further supports the contextual evidence for a population undergoing accelerated growth, significant social change, necessitating the navigation of interaction between two populations and one of a unified and close community wherein a treponeme could spread with relative ease.

\section{Acknowledgments}

We would like to thank Dr. Ngo Anh Son, Mr. Bui Van Khanh, and Ms. Nellissa Ling for their assistance with the radiographs, and Dr. Anne Marie E. Snoddy for input on the application of a standardized approach to treponemal disease. We thank the associate editor of Bioarchaeology International and three anonymous reviewers for their comments and advice in revising the manuscript.

\section{Author Contributions}

MV wrote majority of the manuscript and performed data collection and processing. HRB contributed to research design, assisted in data processing, and contributed substantially to the manuscript. MFO and KD contributed to research design, provided preliminary data, and contributed to the manuscript. TTM facilitated access to collections, assisted with the data collection, and provided Vietnamese translation of the abstract. NTM, HM, HHT, and NTH facilitated access to collections and provided essential background 
knowledge for the production of this publication. $\mathrm{TH}$ and $\mathrm{CH}$ contributed radiocarbon dates for the publication and produced the supplementary information on the radiocarbon dates. All authors critically reviewed, revised, and edited the content of the manuscript.

\section{References}

Acosta, Frank L., Cynthia T. Chin, Alfredo Quiñones-Hinojosa, Christopher P. Ames, Philip R. Weinstein, and Dean Chou. 2004. Diagnosis and management of adult pyogenic osteomyelitis of the cervical spine. Neurosurgical Focus 17(6):1-9.

Acsádi, György, János Nemeskéri, and Kornél Balás. 1970. History of Human Life Span and Mortality. Akademiai kiado, Budapest, Hungary.

Akrawi, Fathallah. 1949. Is bejel syphilis? British Journal of Venereal Diseases 25(3):115-123.

Al-Shahed, Mona S., Hassan S. Sharif, Maurice C. Haddad, Mohamed Y. Aabed, Bassam M. Sammak, and Mohamed A. Mutairi. 1994. Imaging features of musculoskeletal brucellosis. Radiographics 14(2):333-348.

Armelagos, George J., and Mark Nathan Cohen. 1984. Paleopathology at the Origins of Agriculture. Academic Press, New York, USA.

Baker, Brenda J., Gillian Crane-Kramer, Michael W. Dee, Lesley A. Gregoricka, Maciej Henneberg, Christine Lee, Sheila A. Lukehart, David C. Mabey, Charlotte A. Roberts, and Ann L. W. Stodder. 2020. Advancing the understanding of treponemal disease in the past and present. Yearbook of Physical Anthropology. DOI: Early view.

Bellwood, Peter. 2005. First Farmers: The Origins of Agricultural Societies. Blackwell Publishing, Oxford, UK.

Bellwood, Peter, and Marc Oxenham. 2008. The expansions of farming societies and the role of the neolithic demographic transition. In The Neolithic Demographic Transition and Its Consequences, edited by Jean-Pierre Bocquet-Appel and Ofer Bar-Yosef. Springer Science+Business Media, Berlin, pp. 13-34.

Brackett, William Janika, and Todd B. Standley. 2019. Simulating non-accidental trauma with worsening findings: Congenital syphilis. SN Comprehensive Clinical Medicine 1(8):571-574.

Brickley, Megan, and Rachel Ives. 2008. The Bioarchaeology of Metabolic Bone Disease. Academic Press, Oxford, UK.

Brooks, Sheilagh, and Judy M. Suchey. 1990. Skeletal age determination based on the os pubis: A comparison of the AcsádiNemeskéri and Suchey-Brooks methods. Human Evolution 5(3):227-238. DOI: 10.1007/BF02437238.

Buckley, Hallie R. 2016. Health and Disease in the Prehistoric Pacific Islands. BAR International Series 2792. British Archaeological Reports Ltd, Oxford, UK.

Buckley, Hallie R., and George J. Dias. 2002. The distribution of skeletal lesions in treponemal disease: Is the lymphatic system responsible? International Journal of Osteoarchaeology 12(3): 178-188.

Buckley, Hallie R., and Marc F. Oxenham. 2016. Bioarchaeology in the Pacific islands: A temporal and geographical examination of nutritional and infectious disease. In The Routledge Handbook of Bioarchaeology in Southeast Asia and the Pacific, edited by Marc Fredrick Oxenham and Hallie Buckley. Routledge, London, pp. 363-388.

Buikstra, Jane E., and Douglas H. Ubelaker. 1994. Standards for Data Collection from Human Skeletal Remains: Proceedings of a Seminar at the Field Museum of Natural History, Arkansas
Archaeological Survey Research Series No. 44. Arkansas Archaeological Survey, Fayetteville, USA.

Caffey, John. 1939. Syphilis of the skeleton in early infancy: The nonspecificity of many of the roentgenographic changes. American Journal of Roentgenology 42:637-655.

Campbell, G. A., L. G. Adams, and B. A. Sowa. 1994. Mechanisms of binding of Brucella abortus to mononuclear phagocytes from cows naturally resistant or susceptible to brucellosis. Veterinary Immunology and Immunopathology 41(3-4):295-306.

Chan, T. Y. K. 2000. Vitamin D deficiency and susceptibility to tuberculosis. Calcified Tissue International 66(6):476-478.

Cohen, Mark Nathan, and Gillian Margaret Mountford CraneKramer. 2007. Ancient Health: Skeletal Indicators of Agricultural and Economic Intensification. University Press of Florida, Gainesville.

Corr, Peter D. 2011. Musculoskeletal fungal infections. Seminars in Musculoskeletal Radiology 15(5):506-510.

Csonka, G. W. 1953. Clinical aspects of bejel. British Journal of Venereal Diseases 29(2):95-103.

d'Anastasio, Ruggero, T. Staniscia, M. L. Milia, Lamberto Manzoli, and Lorenzo Capasso. 2011. Origin, evolution and paleoepidemiology of brucellosis. Epidemiology \& Infection 139(1): 149-156.

Davidson, Paul T., and Isaac Horowitz. 1970. Skeletal tuberculosis: A review with patient presentations and discussion. The American Journal of Medicine 48(1):77-84.

Dax, E. Cunningham, and R. M. Stewart. 1939. The sign of the clavicle. British Medical Journal 1(4084):771-772.

De la Rua-Domenech, Ricardo. 2006. Human Mycobacterium bovis infection in the United Kingdom: Incidence, risks, control measures and review of the zoonotic aspects of bovine tuberculosis. Tuberculosis 86(2):77-109.

Domett, Kate M., and Hallie R. Buckley. 2012. Large lytic cranial lesions: A differential diagnosis from pre-Angkorian Cambodia. International Journal of Osteoarchaeology 22(6):731-739. DOI: 10.1002/oa.1234.

Domett, Kate M., and Marc F. Oxenham. 2011. The demographic profile of the Man Bac Cemetery sample. In Man Bac: The Excavation of a Neolithic Site in Northern Vietnam, The Biology. Terra Australis 33, edited by Marc Fredrick Oxenham, H. Matsumura, and Nguyen Kim Dung. ANU ePress, Canberra, Australia, pp. 9-20.

Eichelmann, K., S. E. González González, J. C. Salas-Alanis, and J. Ocampo-Candiani. 2013. Leprosy. An update: Definition, pathogenesis, classification, diagnosis, and treatment. Actas Dermo-Sifiliográficas (English Edition) 104(7):554-563.

Engelhardt, H. K. 1959. A study of yaws (Does congenital yaws occur?). Journal of Tropical Medicine and Hygiene 62(10): $238-240$.

Faget, G. H., and A. Mayoral. 1944. Bone changes in leprosy: A clinical and roentgenologic study of 505 cases. Radiology 42(1):1-13.

Fiumara, Nicholas J., and Simmons Lessell. 1970. Manifestations of late congenital syphilis: An analysis of 271 patients. Archives of Dermatology 102(1):78-83.

Flynn, JoAnne L., and John Chan. 2001. Immunology of tuberculosis. Annual Review of Immunology 19(1):93-129.

Franco, María Pía, Maximilian Mulder, Robert H. Gilman, and Henk L. Smits. 2007. Human brucellosis. The Lancet Infectious Diseases 7(12):775-786.

Frangos, Constantinos C., Giagkos M. Lavranos, and Christos C. Frangos. 2011. Higoumenakis' sign in the diagnosis of congenital syphilis in anthropological specimens. Medical Hypotheses 77(1):128-131.

Giaccai, L., and H. Idriss. 1952. Osteomyelitis due to salmonella infection. The Journal of Pediatrics 41(1):73-78. 
Guimarães, F. Nery. 1953. Yaws in Brazil. Bulletin of the World Health Organization 8(1-3):225.

Hackett, Cecil John. 1946. The clinical course of yaws in Lango, Uganda. Transactions of the Royal Society of Tropical Medicine and Hygiene 40(3):205-227.

Hackett, Cecil John. 1951. Bone Lesions of Yaws in Uganda. Blackwell Scientific Publications, Oxford, UK.

Hackett, Cecil John. 1953a. Extent and nature of the yaws problem in Africa. Bulletin of the World Health Organization 8(1-3):127-182.

Hackett, Cecil John. 1953b. The natural history of yaws. Transactions of the Royal Society of Tropical Medicine and Hygiene 47(4):318-320.

Hackett, Cecil John. 1974. Possible treponemal changes in a Tasmanian skull. Man 9(3):436-443.

Hackett, Cecil John. 1975. An introduction to diagnostic criteria of syphilis, treponarid and yaws (treponematoses) in dry bones, and some implications. Virchows Archive A 368(3):229-241.

Hackett, Cecil John. 1976. Diagnostic Criteria of Syphilis, Yaws and Treponarid (Treponematoses) and of Some Other Diseases in Dry Bones. Springer, Berlin.

Hackett, Cecil John. 1978. Treponematoses (yaws and treponarid) in exhumed Australian Aboriginal bones. Records of the South Australian Museum Adelaide 17(27):307-406.

Haque, Abida K. 1990. The pathology and pathophysiology of mycobacterial infections. Journal of Thoracic Imaging 5(2):8-16.

Harper, Kristin N., Molly K Zuckerman, Megan L. Harper, John D. Kingston, and George J. Armelagos. 2011. The origin and antiquity of syphilis revisited: An appraisal of Old World pre-Columbian evidence for treponemal infection. American Journal of Physical Anthropology 146(S53):99-133. DOI: 10.1002 lajpa.21613.

Higham, C. F. W, Xie Guangmao, and Lin Qiang. 2011. The prehistory of a friction zone: First farmers and hunters-gatherers in Southeast Asia. Antiquity 85(328):529-543.

Hill, Kenneth R. 1953. Non-specific factors in the epidemiology of yaws. Bulletin of the World Health Organization 8(1-3):17.

Hillson, Simon, Caroline Grigson, and Sandra Bond. 1998. Dental defects of congenital syphilis. American Journal of Physical Anthropology 107(1):25-40.

Honda, Hitoshi, and Jay R. McDonald. 2009. Current recommendations in the management of osteomyelitis of the hand and wrist. The Journal of Hand Surgery 34(6):1135-1136.

Hook, Edward W., III, and Christina M. Marra. 1992. Acquired syphilis in adults. New England Journal of Medicine 326(16): 1060-1069.

Hume, David A. 2006. The mononuclear phagocyte system. Current Opinion in Immunology 18(1):49-53.

Ikpeme, I. A., N. E. Ngim, and A. A. Ikpeme. 2010. Diagnosis and treatment of pyogenic bone infections. African Health Sciences 10(1):82-88.

Jaffe, Henry Lewis. 1972. Metabolic, Degenerative, and Inflammatory Diseases of Bones and Joints. Lea and Febiger, London.

Johns, David. 1970. Syphilitic disorders of the spine: Report of two cases. The Journal of Bone and Joint Surgery. British Volume 52(4):724-731.

Jones, B. S. 1972. Doigt en lorgnette and concentric bone atrophy associated with healed yaws osteitis: Report of two cases. The Journal of Bone and Joint Surgery. British Volume 54(2):341-345.

Jones, Rebecca K., Philip J. Piper, Colin P. Groves, Tuấn Nguyễn Anh, Mai Huong Nguyễn Thi, Hảo Nguyễn Thị, Trinh Hiep Hoang, and Marc F. Oxenham. 2019. Shifting subsistence patterns from the terminal Pleistocene to late Holocene: A regional Southeast Asian analysis. Quaternary International 529:47-56.

Jones, Roger C., and Robert A. Goodwin Jr. 1981. Histoplasmosis of bone. The American Journal of Medicine 70(4):864-866.
Kazadi, Walter M., Kingsley B. Asiedu, Nsiire Agana, and Oriol Mitjà. 2014. Epidemiology of yaws: An update. Clinical Epidemiology 6:119.

Key, J. Albert. 1940. The pathology of tuberculosis of the spine. The Journal of Bone and Joint Surgery 22(3):799-806.

Kharbanda, Y., and R. S. Dhir. 1991. Natural course of hematogenous pyogenic osteomyelitis (A retrospective study of 110 cases). Journal of Postgraduate Medicine 37(2):69.

Khoach, Nguyen Ba. 1980. Phung Nguyen. Asian Perspectives 23(1):23-54.

Knechel, Nancy A. 2009. Tuberculosis: Pathophysiology, clinical features, and diagnosis. Critical Care Nurse 29(2):34-43.

LaFond, Edward M. 1958. An analysis of adult skeletal tuberculosis. The Journal of Bone and Joint Surgery 40(2):346-364.

Larsen, Clark S. 1995. Biological changes in human populations with agriculture. Annual Review of Anthropology 24(1):185-213. DOI: 10.1146/annurev.an.24.100195.001153.

Larsen, Clark S. 2006. The agricultural revolution as environmental catastrophe: Implications for health and lifestyle in the Holocene. Quarternary International 150(1):12-20. DOI: 10.1016 /j.quaint.2006.01.004.

Lewis, Mary E. 2017. Paleopathology of Children: Identification of Pathological Conditions in the Human Skeletal Remains of Nonadults. Academic Press, London.

Lipson, Mark, Olivia Cheronet, Swapan Mallick, Nadin Rohland, Marc Oxenham, Michael Pietrusewsky, Thomas Oliver Pryce, Anna Willis, Hirofumi Matsumura, and Hallie Buckley. 2018. Ancient genomes document multiple waves of migration in Southeast Asian prehistory. Science 361(6397):92-95. DOI: 10 $.1126 /$ science.aat3188.

Maas, Marioo, Erik J. Slim, Agnes F. Heoksma, Ad J. van der Kleij, Erik M. Akkerman, Gerardd J. den Heeten, and William R. Faber. 2002. MR imaging of neuropathic feet in leprosy patients with suspected osteomyelitis. International Journal of Leprosy and Other Mycobacterial Diseases 70(2):97-103.

Marks, Michael, Anthony W. Solomon, and David C. Mabey. 2014. Endemic treponemal diseases. Transactions of the Royal Society of Tropical Medicine and Hygiene 108(10):601-607.

Mata, Leonardo J. 1975. Malnutrition-infection interactions in the tropics. The American Journal of Tropical Medicine and Hygiene 24(4):564-574.

Matsumura, Hirofumi. 2011a. Quantitative and qualitative dental-morphology at Man Bac. In Man Bac: The Excavation of a Neolithic Site in Northern Vietnam, The Biology. Terra Australis 33, edited by Marc Fredrick Oxenham, Hirofumi Matsumura and Nguyen Kim Dung. ANU ePress, Canberra, Australia, pp. 43-63.

Matsumura, Hirofumi. 2011b. Quantitative cranio-morphology at Man Bac. In Man Bac: The Excavation of a Neolithic Site in Northern Vietnam. The Biology, Terra Australis 33, edited by Marc Fredrick Oxenham, Hirofumi Matsumura, and Nguyen Kim Dung. ANU ePress, Canberra, Australia, pp. 21-32.

Matsumura, Hirofumi, Hsiao-chun Hung, Charles Higham, Chi Zhang, Mariko Yamagata, Lan Cuong Nguyen, Zhen Li, Xuechun Fan, Truman Simanjuntak, and Adhi Agus Oktaviana. 2019. Craniometrics reveal "two layers" of prehistoric human dispersal in Eastern Eurasia. Scientific Reports 9(1):1451.

Matsumura, Hirofumi, and Marc Oxenham. 2013a. Eastern Asia and Japan: Human biology. In The Encyclopedia of Global Human Migration, edited by Immanuel Ness. Wiley-Blackwell, Chichester, UK, pp. 217-223.

Matsumura, Hirofumi, and Marc Oxenham. 2013b. Population dispersal from East Asia into Southeast Asia: Evidence from cranial and dental morphology. In Bioarchaeology of East Asia: Movement, Contact, Health, edited by Ekaterina A. Pechenkina and M. F. Oxenham. University Press of Florida, Gainesville, pp. 179-212. 
Matsumura, Hirofumi, and Marc Oxenham. 2014. Demographic transitions and migration in prehistoric East/Southeast Asia through the lens of nonmetric dental traits. American Journal of Physical Anthropology 155(1):45-65. DOI: 10.1002/ajpa.22537.

Matsumura, Hirofumi, Marc F. Oxenham, Yukio Dodo, Kate Domett, Nguyen Kim Thuy, Nguyen Lan Cuong, Nguyen Kim Dung, Damien Huffer and Mariko Yamagata. 2008. Morphometric affinity of the Late Neolithic human remains from Man Bac, Ninh Binh Province, Vietnam: Key skeletons with which to debate the "two layer" hypothesis. Anthropological Science 116(2):135-148. DOI: 10.1537/ase.070405

Mays, Simon. 2012. The relationship between paleopathology and the clinical sciences. In A Companion to Paleopathology, edited by Anne L. Grauer. Wiley-Blackwell, Oxford, UK, pp. 285-309.

McColl, Hugh, Fernando Racimo, Lasse Vinner, Fabrice Demeter, Takashi Gakuhari, J Víctor Moreno-Mayar, George Van Driem, Uffe Gram Wilken, Andaine Seguin-Orlando, and Constanza De la Fuente Castro. 2018. The prehistoric peopling of Southeast Asia. Science 361(6397):88-92. DOI: 10.1126/science .aat3628.

McDonell, Amy, and Marc F. Oxenham. 2014. Localised primary canine hypoplasia: implications for maternal and infant health at Man Bac, Vietnam, 4000-3500 years BP. International Journal of Osteoarchaeology 24(4):531-539. DOI: 10.1002/oa.2239.

McFadden, Clare, Hallie Buckley, Sian E. Halcrow, and Marc F. Oxenham. 2018. Detection of temporospatially localized growth in ancient Southeast Asia using human skeletal remains. Journal of Archaeological Science 98:93-101. DOI: 10.1016/j.jas.2018.08.010.

Meheus, André, and G. M. Antal. 1992. The endemic treponematoses: Not yet eradicated. World Health Statistics Quarterly 45:228-228.

Mehmet, F. G., G. Ali, N. Kemal, Ç. Remzi, S. Jale, D. Bunyamin, and A. Celal. 2002. Musculoskeletal involvement in brucellosis in different age groups: A study of 195 cases. Swiss Medical Weekly 132(0708).

Miller, G. A. H., Mark Ridley, and W. E. Medd. 1963. Typhoid osteomyelitis of the spine. British Medical Journal 1(5337):1068.

Mitjà, Oriol, Kingsley Asiedu, and David Mabey. 2013. Yaws. The Lancet 381(9868):763-773. DOI: 10.1016/S0140-6736(12)62130-8.

Møller-Christensen, Vilhelm. 1961. Bone Changes in Leprosy. Munksgaard, Copenhagen.

Møller-Christensen, Vilhelm. 1978. Leprosy Changes of the Skull. Odense University Press, Odense, Denmark.

Møller-Christensen, Vilhelm, Sigvald N. Bakke, Reider S. Melsom, and Erik Waaler. 1952. Changes in the anterior nasal spine and the alveolar process of the maxillary bone in leprosy. International Journal of Leprosy 20:335-340.

Moorrees, Coenraad F. A., Elizabeth A. Fanning, and Edward E. Hunt Jr. 1963. Age variation of formation stages for ten permanent teeth. Journal of Dental Research 42(6):1490-1502.

Nguyen, Kim Dung. 2008. The scientific cooperation program at Man Bac (2004-2007): Results and questions. Paper presented at the International Forum on the Prehistoric Man Bac Site, The Institute of Archaeology, Vietnam Academy of Social Sciences Institute, Hanoi.

Nussenblatt, Veronique, and Richard D. Semba. 2002. Micronutrient malnutrition and the pathogenesis of malarial anemia. Acta Tropica 82(3):321-337.

Ortner, Donald J. 2003. Identification of Pathological Conditions in Human Skeletal Remains. Academic Press, San Diego, USA.

Ortner, Donald J. 2011. Human skeletal paleopathology. International Journal of Paleopathology 1(1):4-11.

Oxenham, Marc, and Hallie Buckley. 2016. The Routledge Handbook of Bioarchaeology in Southeast Asia and the Pacific Islands. Routledge, New York.

Oxenham, Marc F., and Kate M. Domett. 2011. Palaeohealth at Man Bac. In Man Bac: The Excavation of a Neolithic Site in
Northern Vietnam. The Biology, Terra Australis 33. edited by Marc Fredrick Oxenham, Hirofumi Matsumura, and Nguyen Kim Dung. ANU ePress, Canberra, Australia, pp. 77-93.

Oxenham, Marc Fredrick, Hirofumi Matsumura, and Nguyen Kim Dung, eds. 2011. Man Bac: The Excavation of a Neolithic Site in Northern Vietnam. The Biology, Terra Australis 33. ANU ePress, Canberra, Australia.

Oxenham, Marc F., Philip J. Piper, Peter Bellwood, Chi Hoang Bui, Khanh Trung Kien Nguyen, Quoc Manh Nguyen, Fredeliza Campos, Cristina Castillo, Rachel Wood, and Carmen Sarjeant. 2015. Emergence and diversification of the neolithic in southern Vietnam: Insights from coastal Rach Nui. The Journal of Island and Coastal Archaeology 10(3):309-338.

Oxenham, Marc F., Nguyen Kim Thuy, and Nguyen Lan Cuong. 2005. Skeletal evidence for the emergence of infectious disease in Bronze and Iron Age northern Vietnam. American Journal of Physical Anthropology 126(4):359-376. DOI: 10.1002/ajpa .20048 .

Oxenham, Marc F., Lorna Tilley, Hirofumi Matsumura, Lan Cuong Nguyen, Kim Thuy Nguyen, Kim Dung Nguyen, Kate Domett, and Damien Huffer. 2009. Paralysis and severe disability requiring Intensive care in neolithic Asia. Anthropological Science 117(2):107-112. DOI: 10.1537/ase.081114.

Oxenham, Marc F., Hiep Hoang Trinh, Anna Willis, Rebecca K Jones, Kathryn Domett, Cristina Castillo, Rachel Wood, Peter Bellwood, Monica Tromp, and Ainslee Kells. 2018. Between foraging and farming: Strategic responses to the holocene thermal maximum in Southeast Asia. Antiquity 92(364):940-957. DOI: 10.15184/aqy.2018.69.

Pavithran, Kuyyalil. 1987. Acquired syphilis in a patient with late congenital syphilis. Sexually Transmitted Diseases 14(2):119-121.

Peeling, Rosanna W., and Edward W. Hook III. 2006. The pathogenesis of syphilis: The great mimicker, revisited. The Journal of Pathology: A Journal of the Pathological Society of Great Britain and Ireland 208(2):224-232.

Pelletier, David L., Edward A. Frongillo Jr., Dirk G. Schroeder, and Jean-Pierre Habicht. 1995. The effects of malnutrition on child mortality in developing countries. Bulletin of the World Health Organization 73(4):443.

Pessoa, Larissa, and Virgilio Galvão. 2011. Clinical aspects of congenital syphilis with Hutchinson's triad. Case Reports 2011: bcr1120115130.

Phenice, Terrell Wayne. 1969. A newly developed visual method of sexing the os pubis. American Journal of Physical Anthropology 30(2):297-301.

Pitt, Michael J. 1995. Rickets and osteomalacia. In Diagnosis of Bone and Joint Disorders, edited by Donald Resnick. Saunders, Philadelphia, pp. 1885-1922.

Powell, Mary Lucas, and Della Collins Cook. 2005. The Myth of Syphilis: The Natural History of Treponematosis in North America. University Press of Florida, Gainesville.

Rana, Rich S., Jim S. Wu, and Ronald L. Eisenberg. 2009. Periosteal reaction. American Journal of Roentgenology 193(4):259-272.

Rasool, M. N., and S. Govender. 1989. The skeletal manifestations of congenital syphilis. A review of 197 cases. The Journal of Bone and Joint Surgery. British Volume 71(5):752-755.

Resnick, Donald, ed. 1995a. Diagnosis of Bone and Joint Disorders. Saunders, Philadelphia.

Resnick, Donald. 1995b. Hypervitaminosis and hypovitaminosis. In Diagnosis of Bone and Joint Disorders, edited by Donald Resnick. Saunders, Philadelphia, pp. 3343-3352.

Resnick, Donald, and Gen Niwayama. 1995. Osteomyelitis, septic arthritis and soft tissue infection: Organisms. In Diagnosis of Bone and Joint Disorders, edited by Donald Resnick. Saunders, Philadelphia, pp. 2448-2558.

Ridley, N., M. I. Shaikh, D. Remedios, and R. Mitchell. 1998. Radiology of skeletal tuberculosis. Orthopedics 21(11):1213-1220. 
Roberts, Charlotte. 2000. Infectious disease in biocultural perspective: Past, present and future work in Britain. In Human Osteology in Archaeology and Forensic Science, edited by Margaret Cox and Simon Mays. Greenwich Medical Media, London, pp. 145-162.

Roberts, Charlotte. 2012. Re-emerging infections: Developments in bioarchaeological contributions to understanding tuberculosis. In A Companion to Paleopathology, edited by Anne L. Grauer. Wiley-Blackwell, Oxford, UK, pp. 434-457.

Roberts, Charlotte. 2019. Infectious disease: Introduction, periostosis, periostitis, osteomyelitis, and septic arthritis. In Ortner's Identification of Pathological Conditions in Human Skeletal Remains, edited by Jane E. Buikstra. 3rd ed. Elsevier, San Diego, pp. 285-319.

Roberts, Charlotte A., and Megan Brickley. 2018. Infectious and metabolic diseases: A synergistic relationship. In Biological Anthropology of the Human Skeleton, edited by M. Anne Katzenberg and Anne L. Grauer. John Wiley \& Sons, New York, pp. 415-446.

Roberts, Charlotte A., and Jane E. Buikstra. 2019. Bacterial infections. In Ortner's Identification of Pathological Conditions in Human Skeletal Remains, edited by Jane E. Buikstra. 3rd ed. Elsevier, San Diego, pp. 321-439.

Ruiz, Bernardo, Jennifer Carlton Rood, Elizabeth T. H. Fontham, Gray T. Malcom, Fred M. Hunter, Mahboob Sobhan, William D. Johnson, and Pelayo Correa. 1994. Vitamin C concentration in gastric juice before and after anti-Helicobacter pylori treatment. American Journal of Gastroenterology 89(4):533-539.

Samarkos, Michael, Charis Giannopoulou, Eleni Karantoni, Vassileios Papastamopoulos, Ioannis Baraboutis, and Athanassios Skoutelis. 2011. Syphilitic periostitis of the skull and ribs in a HIV positive patient. Sexually Transmitted Infections 87(1): 44-45.

Sandison, A. T. 1980. Notes on some skeletal changes in preEuropean contact Australian aborigines. Journal of Human Evolution 9(1):45-47.

Saonere, Jyotsna A. 2011. Leprosy: An overview. Journal of Infectious Diseases and Immunity 3(14):233-243.

Sawada, Junmei, Nguyen Kim Thuy, and Nguyen Anh Tuan. 2011. Faunal remains at Man Bac. In Man Bac: The Excavation of a Neolithic Site in Northern Vietnam, The Biology. Terra Australis 33, edited by Marc Fredrick Oxenham, Hirofumi Matsumura, and Nguyen Kim Dung. ANU ePress, Canberra, Australia, pp. 105-116.

Scheuer, Louise, and Sue Black. 2000. Developmental Juvenile Osteology. Academic Press, Oxford, UK.

Sequeira, W. 1994. The neuropathic joint. Clinical and Experimental Rheumatology 12(3):325-337.

Snoddy, Anne Marie E., Julia Beaumont, Hallie R. Buckley, Antony Colombo, Siân E Halcrow, Rebecca L. Kinaston, and Melandri Vlok. 2020. Sensationalism and speaking to the public: Scientific rigour and interdisciplinary collaborations in palaeopathology. International Journal of Paleopathology 28:88-91.

Snoddy, Anne Marie E., Hallie R. Buckley, Gail E. Elliott, Vivien G. Standen, Bernardo T. Arriaza, and Siân E. Halcrow. 2018. Macroscopic features of scurvy in human skeletal remains: A literature synthesis and diagnostic guide. American Journal of Physical Anthropology 167(4):876-895. DOI: 10.1002 /ajpa.23699.

Snoddy, Anne Marie E., Siân E. Halcrow, Hallie R. Buckley, Vivien G. Standen, and Bernardo T. Arriaza. 2017. Scurvy at the agricultural transition in the Atacama Desert (ca 36003200 BP): Nutritional stress at the maternal-foetal interface? International Journal of Paleopathology 18:108-120. DOI: 10.1016 /j.ijpp.2017.05.011.
Stokes, John H., and Boyd S. Gardner. 1923. The demonstration of unerupted Hutchinson's teeth by the roentgen ray. Journal of the American Medical Association 80(1):28-29.

Stuart-Macadam, Patty. 1985. Porotic hyperostosis: Representative of a childhood condition. American Journal of Physical Anthropology 66(4):391-398.

Swezey, Robert L., David M. Bjarnason, Stanley J. Alexander, and D. B. Forrester. 1972. Resorptive arthropathy and the operaglass hand syndrome. Seminars in Arthritis and Rheumatism 2(3):191-244.

Taljanovic, Mihra S., and Rodney D. Adam. 2011. Musculoskeletal coccidioidomycosis. Seminars in Musculoskeletal Radiology 15(5):511-526.

Tanabe, Susumu, Yoshiki Saito, Quang Lan Vu, Till J. J. Hanebuth, Quang Lan Ngo, and Akihisa Kitamura. 2006. Holocene evolution of the Song Hong (Red River) delta system, northern Vietnam. Sedimentary Geology 187(1-2):29-61.

Tayles, Nancy, and Hallie R. Buckley. 2004. Leprosy and tuberculosis in Iron Age Southeast Asia? American Journal of Physical Anthropology 125(3):239-256. DOI: 10.1002/ajpa.10378.

Temple, Daniel H. 2010. Patterns of systemic stress during the agricultural transition in prehistoric Japan. American Journal of Physical Anthropology 142(1):112-124. DOI: 10.1002/ajpa.21208.

Teo, Harvey E. L., and Wilfred C. G. Peh. 2004. Skeletal tuberculosis in children. Pediatric Radiology 34(11):853-860.

Tilley, Lorna, and Marc F. Oxenham. 2011. Survival against the odds: Modeling the social implications of care provision to seriously disabled individuals. International Journal of Paleopathology 1(1):35-42. DOI: 10.1016/j.ijpp.2011.02.003.

Tilley, Lorna, and Marc F. Oxenham. 2016. Reflections on life and times in Neolithic Vietnam: One person's story. In The Routledge Handbook of Bioarchaeology in Southeast Asia and the Pacific, edited by Marc Fredrick Oxenham and Hallie Buckley. Routledge, London, pp. 95-113.

Toizumi, Takeji, Nguyen Kim Thuy, and Junmei Sawada. 2011. Fish remains at Man Bac. In Man Bac: The Excavation of a Neolithic Site in Northern Vietnam. The Biology, Terra Australis 33, edited by Marc Fredrick Oxenham, Hirofumi Matsumura, and Nguyen Kim Dung. ANU ePress, Canberra, Australia, pp. 117-126.

Toone, Elam C., Jr., and John Kelly. 1956. Joint and bone disease due to mycotic infection. Transactions of the American Clinical and Climatological Association 67:91-103.

Turgut, Mehmet. 2001. Spinal tuberculosis (Pott's disease): Its clinical presentation, surgical management, and outcome. A survey study on 694 patients. Neurosurgical Review 24(1):8-13.

Ubelaker, Douglas H. 1999. Human Skeletal Remains: Excavation, Analysis, Interpretation. 3rd ed. Aldine Manuals on Archaeology. Taraxacum Press, Washington, D.C.

Vohra, Rajeev, Harinder S. Kang, Sameer Dogra, Radha R. Saggar, and Rajan Sharma. 1997. Tuberculous osteomyelitis. The Journal of Bone and Joint Surgery. British Volume 79(4):562-566.

Weston, Darlene A. 2012. Nonspecific infection in paleopathology: Interpreting periosteal reactions. In A Companion to $\mathrm{Pa}$ leopathology, edited by Anne L Grauer. John Wiley \& Sons, Chichester, UK, pp. 492-512.

Willcox, R. R. 1974. Changing patterns of treponemal disease. British Journal of Venereal Diseases 50(3):169.

World Health Organization. 2013. Global Tuberculosis Report 2013.

Yang, K. L. 1940. Clavicle sign of late congenital syphilis: Review of literature and report of six cases. Archives of Dermatology and Syphilology 41(6):1060-1065.

Zuckerman, Molly K., Kristin N. Harper, and George J. Armelagos. 2016. Adapt or die: Three case studies in which the failure to adopt advances from other fields has compromised paleopathology. International Journal of Osteoarchaeology 26(3):375-383. 